\title{
Secrets of a Head Chef: Exploring Factors Influencing Success in Irish Kitchens
}

\author{
Máirtín Mac Con lomaire \\ Technological University Dublin, mairtin.macconiomaire@tudublin.ie \\ Hannah Allen \\ Technological University Dublin, hannahallen25@hotmail.com
}

Follow this and additional works at: https://arrow.tudublin.ie/tfschafart

Part of the Food Studies Commons

\section{Recommended Citation \\ Mac Con lomaire, M. \& Allen, Hannah. 2016. Secrets of a Head Chef: Exploring Factors Influencing Success in Irish Kitchens. Journal of Culinary Science \& Technology, vol 15, no. 3, pp. 187-222. doi:10.1080/15428052.2016.1225538}

This Article is brought to you for free and open access by the School of Culinary Arts and Food Technology at ARROW@TU Dublin. It has been accepted for inclusion in Articles by an authorized administrator of ARROW@TU Dublin. For more information, please contact arrow.admin@tudublin.ie, aisling.coyne@tudublin.ie, gerard.connolly@tudublin.ie.

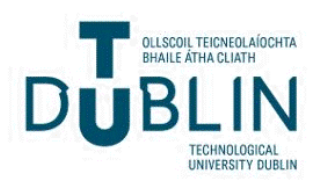




\title{
Secrets of a Head Chef: Exploring Factors Influencing Success in Irish Kitchens
}

\author{
Hannah Allen and Máirtín Mac Con lomaire (B) \\ School of Culinary Arts \& Food Technology, Dublin Institute of Technology, Dublin, Ireland
}

\begin{abstract}
One-hundred and seventy head chefs from the Republic of Ireland scored 59 variables for success on two scales: (a) competencies needed for success (NS), and (b) personal ownership of these competencies (PO). Results showed that variables were rated with means of 1.18 (extremely important) to 3.23 (moderately important). The top three were an ability to work hard, commitment to quality, and knowledge of Hazard Analysis and Critical Control Points (HACCP). Variables rated lower in ownership than importance highlight areas for culinary educators to develop training programs. Average wages of head chefs (objective success) mirror the average industrial wage, but higher wages were gained with longer time working. Eighty percent of head chefs were satisfied (subjective success) in their current jobs. Factor analysis showed the factors needed to succeed in the culinary industry include professionalism, individual characteristics, leadership skills, management skills, and interaction with the job context. Applications for industry include talent management, mentoring future leaders, reducing staff turnover, and curriculum development.
\end{abstract}

\section{ARTICLE HISTORY}

Received 12 May 2016

Accepted 26 July 2016

\section{KEYWORDS}

Competencies; head chef; Ireland; objective success; subjective success

\section{Introduction}

The hospitality sector is one of the most important services sectors in the Irish economy. It directly employs 158,000 persons within 16,000 enterprises. This represents $8 \%$ of current economy-wide employment. The sector contributes $€ 3$ billion gross value added to the economy. On a comparative level, Ireland was ranked fifth in the EU in relation to the proportion of overall economywide employment accounted for by the hospitality-related accommodation and food services sector, behind Greece, Spain, Cyprus, and Malta, representing 7.3\% of economy-wide employment. Ireland is currently experiencing a chronic severe shortage of chefs (EGFSN, 2015).

The aim of this study was to examine what it takes to succeed in the culinary industry. Head chefs have succeeded at the top of their profession and therefore have gained valuable experiences and insights into what it takes

CONTACT Máirtín Mac Con lomaire mairtin.macconiomaire@dit.ie 0 School of Culinary Arts \& Food Technology, Dublin Institute of Technology, Cathal Brugha Street, Dublin 1, Ireland.

Color versions of one or more of the figures in the article can be found online at www.tandfonline.com/wcsc. 
to succeed in the culinary world. Research on chefs is under-represented in the hospitality literature, with research on head chefs particularly rare. Birdir and Pearson (2000) carried out a competencies based study on research chefs, however this sample population represents a small subgroup of the profession of chefs. Balazs' $(2001,2002)$ qualitative study concentrated on three-starred Michelin chefs in France, examining lessons for leadership. Again, this was a very narrowly defined study, presenting more of a narrative on leadership rather than what it takes to succeed, where the scope of the study was different to the current aim of this study. Another study by Zopiatis (2010) examined the competencies for success but used a sample population of the entire kitchen brigade. By sampling the entire kitchen brigade, opinions about competencies for success may differ with experience and progression within the industry. Therefore the current research fills a gap in the literature by using data gathered from those who have already objectively succeeded in the industry, namely head chefs.

Another issue in exploring the factors for success within the culinary industry is which measures of success to use. Previous research has found that success can be defined objectively by attainments such as pay, promotions, and occupational status (Dries, Pepermans, \& Carlier, 2008). Alternatively it can also be defined subjectively using a person's own perception of his accomplishments, future prospects, and sense of career satisfaction (Dries et al., 2008), although, many researchers (Arthur, Khapova, \& Wilderom, 2005; Johnston \& Phelan, 2016; Nicholson \& De Waal-Andrews, 2005) propose that both objective and subjective success are interdependent. Therefore the current research seeks to include both objective and subjective measures of success within the culinary industry.

A common measure of what it takes to succeed is a competency model. Katz (1955) was the first to examine managerial competencies and developed a threecategory model that included technical, human, and conceptual competencies. Sandwith (1993) expanded this model by elaborating and dividing the human competencies into interpersonal, leadership, and administrative competencies. However, in developing a competency model Sandwith (1993) argued that any organization using a competency model would have to adapt it to competencies that are relevant for that business. Zopiatis (2010) successfully developed a competency model for use within the culinary industry. However, in reviewing the literature on competencies and success, it can be seen that more variables have been found to influence success than the ones included in the study by Zopiatis (2010). For example Wang, Horng, Cheng, and Killman (2011) found that the factors influencing food and beverage employees' career success in Taiwan can be broadened to include Bronfenbrenner's (1979) ecology of career development. Wang et al. (2011) demonstrated that it is not just the internal competencies of an individual that enables them to succeed but there is also an interaction with the environment or context in which that individual is placed. 
Another factor to be considered on influencing success, which is not adequately covered by any competency model, is the issue of personality. The literature shows that personality plays a role in mediating the individual's perceptions about his own career success (Judge, Higgins, Thoresen, \& Barrick, 1999; Melamed, 1996; Seibert \& Kraimer, 2001; Wu, Foo, \& Turban, 2008). Therefore the current study was envisioned to have a theoretical framework that was broad enough to take account of competencies, environmental factors, and personality factors in order to examine what it takes to succeed as a chef.

The current research furthers our understanding and knowledge of the factors needed to succeed within the professional kitchen by surveying those who have already objectively succeeded within the industry, namely head chefs. This knowledge will benefit future culinary arts students, educators, and current employees in highlighting the factors needed for culinary success. Findings can be used in selecting, developing, coaching, or mentoring tomorrow's industry leaders (Chung-Herrera, Enz, \& Lankau, 2003) by providing insight for employers wishing to identify suitable candidates for promotion to senior positions based on recognition of important characteristics for success. In this regard, they are essential for companies that hope to remain competitive as they can be used to plan for management succession or the selection, recruitment, and training of staff (Sengupta, Venkatesh, \& Sinha, 2013). Understanding the factors contributing to culinary success may also help reduce high levels of turnover within the industry (Allen \& Mac Con Iomaire, 2016; EGFSN, 2015; Lydon, 2012; Robinson \& Beesley, 2010; Sheehan, 2014; Wang et al., 2011), which is a regular issue for employers in the sector and a particular hot topic in the current Irish hospitality industry.

\section{Literature review}

This section sets out the conceptual framework within which the study is set. Research on chefs is underrepresented in the hospitality literature. Historical research on chefs and restaurants has increased in recent years (Davis, 2013; Mac Con Iomaire, 2013, 2014; Mennell, 1996; Spang, 2000). Sociological research on chefs began with Whyte's (1948) study of Chicago restaurants. Wood (1997) noted the lack of methodological work of chefs since Whyte's study as remarkable. Chivers' (1972) doctoral thesis stands out as one of the first to focus particularly on chefs and cooks in the UK, until the work of Fine (1996) in a U.S. context, based on fieldwork in restaurants in Minnesota in the 1980s. Both works are now considerably dated. Research has begun on various aspects of the chefs occupation and culture, including work on kitchen violence and bullying (Alexander, MacLaren, O'Gorman, \& Taheri, 2012; Bloisi \& Hoel, 2008; Johns \& Menzels, 1999), occupational stress (Murray-Gibbons \& Gibbons, 2007), retention and training (Pratten, 2003; Robinson \& Beesley, 2010), liberal education (Hegarty, 2004; Magnusson 
Sporre, Johnson, \& Ekström, 2015), and gender (Bartholomew \& Garey, 1996; Harris \& Giuffre, 2015). However, specific research on head chefs remains extremely rare (Allen \& Mac Con Iomaire, 2016). With this in mind, a thorough analysis of the literature on chefs and career success was carried out, as can be seen in the discussion below and in Table 2 .

\section{Situating the research in an Irish context}

The Irish hospitality industry experienced unprecedented growth during the "Celtic Tiger" years (1994-2007), when dining out moved from an occasional occurrence to a regular pastime. Despite the recession (2008-2014), the numbers of restaurants managed to survive and grow (Mac Con Iomaire, 2014). Ireland has been to the forefront globally in transforming culinary education from a vocational to a liberal paradigm (Hegarty, 2004), with the inauguration of the first BA (hons) in culinary arts in 1999 and the first MSc in culinary innovation in 2007, both at the Dublin Institute of Technology. A culinary arts degree graduate, Mark Moriarty, was crowned San Pellegrino Young Chef 2015, putting Ireland on the global dining map. This was no surprise, as in 2011, the editor of Le Guide du Routard noted, "the Irish dining experience is now as good if not better than anywhere in the world" (Mac Con Iomaire, 2015, p. 371).

However, no precise and comprehensive definition of employment in the hospitality sector exists in official statistical publications, an issue highlighted by Allen and Mac Con Iomaire (2016). The Expert Group on Future Skills Needs report (EGFSN, 2015) provides the latest and most comprehensive figures to date. It is estimated that 157,990 persons were employed in hospitality-related roles in the Irish economy during 2014 (based on a quarterly average). This is presented in Table 1 at a detailed occupation

Table 1. Employment figures in the Irish hospitality sector.

\begin{tabular}{lrc}
\hline $\begin{array}{l}\text { Estimate of employment in hospitality sector in Ireland by occupation- } \\
2014 \text { hospitality-related occupation }\end{array}$ & $\begin{array}{r}2014 \text { (Quarterly } \\
\text { average) }\end{array}$ & $\begin{array}{c}\text { Percentage } \\
\text { of total }\end{array}$ \\
\hline Waiters and waitresses & 27,509 & $17.4 \%$ \\
Chefs & 23,948 & $15.2 \%$ \\
Kitchen and catering assistants & 23,255 & $14.7 \%$ \\
Bar staff & 18,719 & $11.8 \%$ \\
Hotel and accommodation managers and proprietors & 8,242 & $5.2 \%$ \\
Restaurant and catering managers and proprietors & 6,299 & $4 \%$ \\
Catering and bar managers & 5,724 & $3.6 \%$ \\
Sales and retail Assistants & 5,504 & $3.5 \%$ \\
Cleaners and domestics & 3,810 & $2.4 \%$ \\
Publicans and managers of licensed premises & 3,436 & $2.2 \%$ \\
Receptionists & 3,087 & $1.9 \%$ \\
Other occupations* & 28,457 & $18 \%$ \\
Total Hospitality Sector & 157,990 & \\
\hline
\end{tabular}


Table 2. Studies on career success.

\begin{tabular}{|c|c|}
\hline Success variable & Source from literature \\
\hline Ability to delegate & Butler and Skipper (1983) \\
\hline $\begin{array}{l}\text { Ability to get along with others and form } \\
\text { relationships }\end{array}$ & Steinberg (2010); Balazs (2002) \\
\hline Ability to motivate others & Zopiatis (2010); Balazs (2002) \\
\hline Ability to motivate self & Bueno and Tubbs (2004); Zopiatis and Constanti (2007) \\
\hline Ability to organise & Zopiatis (2010); Balazs (2002) \\
\hline Adaptation to difficult circumstances & $\begin{array}{l}\text { Collins (2001); Murray-Gibbons \& Gibbons (2007); } \\
\text { Zopiatis (2010) }\end{array}$ \\
\hline Agreeable & Judge et al. (1999) \\
\hline Appreciation of cost management & Gilbert and Guerrier (1997); Zopiatis (2010) \\
\hline Budgeting & Gilbert and Guerrier (1997); Zopiatis (2010) \\
\hline Career planning & Pratten (2003) \\
\hline Careful & Judge et al. (1999) \\
\hline Commitment to company & $\begin{array}{l}\text { Robinson and Beesley (2010); Wang et al. (2011); } \\
\text { Iverson and Deery (1997) }\end{array}$ \\
\hline Commitment to quality & Balazs (2001); Martin (2004) \\
\hline Communication skills & $\begin{array}{l}\text { Collins (2001); Bueno and Tubbs (2004); Harrington } \\
\text { (2005); LeVine (2007); Zopiatis (2010) }\end{array}$ \\
\hline Computer skills & Zopiatis (2010) \\
\hline Confidence & Melamed (1996); Horng and Lee (2006) \\
\hline Conscientious/Attention to Detail/Diligent & Judge et al. (1999); Cheng (2011) \\
\hline Critical thinking & Nordhaug (1998); Ko (2012); Harrington (2005) \\
\hline Culinary skill & $\begin{array}{l}\text { Balazs (2001); Lee-Ross (2001); Birdir \& Pearson (2000); } \\
\text { Antun and Salazar (2005); Zopiatis and Constanti } \\
\text { (2007); Johnston and Phelan (2016) }\end{array}$ \\
\hline Dealing with change & Zopiatis (2010); Stierand and Lynch (2008) \\
\hline Decision making & Harrington (2005); Steinberg (2010) \\
\hline Desire to remain in the job & Antun and Salazar (2005) \\
\hline Education & $\begin{array}{l}\text { Feingold, Wagner, and Mason (2000); Goyette (2008); } \\
\text { Steinberg (2010); Hertzman and Maas (2012) }\end{array}$ \\
\hline Family support & $\begin{array}{l}\text { Kuijpers et al. (2006); Horng and Lee (2009); } \\
\text { Wang et al. (2011) }\end{array}$ \\
\hline Flexibility & $\begin{array}{l}\text { Balazs (2001); Bueno and Tubbs (2004); Akrivos et al. } \\
\text { (2007); Lydon (2012) }\end{array}$ \\
\hline Fostering teamwork & Balazs (2002); Mac Con lomaire (2008) \\
\hline Having a mentor & $\begin{array}{l}\text { Aryee and Chay (1994); Joiner et al. (2004); Mac Con } \\
\text { lomaire (2008); Bozionelos (2008) }\end{array}$ \\
\hline Having emotional control & Zopiatis (2010) \\
\hline Having received job training & Lydon (2012); LeVine (2007); Wang et al. (2011) \\
\hline Innovation & $\begin{array}{l}\text { Caraher (2012); Robinson and Barron (2007); } \\
\text { Stierand and Lynch (2008); Lydon (2012); }\end{array}$ \\
\hline Internalisation of company goals and objectives & Antun and Salazar (2005) \\
\hline Keeping up to date with current trends & Zopiatis (2010) \\
\hline Knowledge of culinary flavours & Zopiatis (2010) \\
\hline $\begin{array}{l}\text { Knowledge of food safety systems and law e.g. } \\
\text { HACCP }\end{array}$ & Zopiatis (2010) \\
\hline Knowledge of profit and loss & Gilbert and Guerrier (1997); Zopiatis (2010) \\
\hline Knowledge of recipe and menu development & Zopiatis (2010) \\
\hline Length of time with employer & Wang et al. (2011); Antun and Salazar (2005) \\
\hline Open minded & $\begin{array}{l}\text { Judge et al. (1999); Balazs (2001); Seibert and Kraimer } \\
\text { (2001); Bueno and Tubbs (2004); Cheng (2011) }\end{array}$ \\
\hline Opportunity to progress with the company & Collins (2001); Wang et al. (2011) \\
\hline Other job opportunities in the market & $\begin{array}{l}\text { Hui (1988); Iverson and Deery (1997); Brien (2004); } \\
\text { Jauhari (2006) }\end{array}$ \\
\hline Outgoing/Extroverted & Melamed (1996); Judge et al. (1999); Cheng (2011) \\
\hline
\end{tabular}


Table 2. (Continued).

\begin{tabular}{ll}
\hline Success variable & \multicolumn{1}{c}{ Source from literature } \\
\hline Passion & Parseghian (1995); Horng and Lee (2006); Akrivos et al. \\
& $(2007)$ \\
Perseverance & Dreher and Bretz (1991); Pratten (2003); Horng and \\
& Lee (2006) \\
Person-Job fit & Judge et al. (1999); Wang et al. (2011) \\
Physical fitness & Akrivos et al. (2007) \\
Positive attitude & Collins (2001); Zopiatis and Constanti (2007); Iverson \\
& and Deery (1997) \\
Positive atmosphere at work & Collins (2001); Horng and Lee (2009); Wang et al. \\
& (2011) \\
Previous work experience & Seibert and Kraimer (2001); Mesch (2012) \\
Problem solving & Steinberg (2010) \\
Professionalism & Zopiatis (2010); Ko (2012) \\
Respect for others & Bueno and Tubbs (2004); Balazs (2002) \\
Satisfaction with company & Robinson and Beesley (2010); Iverson and Deery (1997) \\
Self discipline & Zopiatis and Constanti (2007) \\
Sensitivity to others & Bueno and Tubbs (2004); Horng and Lee (2006) \\
Social networking & Dreher and Bretz (1991); Kuijpers et al. (2006); Stierand \\
Strategic planning & and Lynch (2008) \\
Time management & Raybould and Wilkins (2005); Harrington (2005) \\
Willingness to work hard & Zopiatis (2010) \\
Work pleasure (enjoying your job) or enthusiasm & Dreher and Bretz (1991); Judge et al. (1995); Pratten \\
& (2003); Antun and Salazar (2005) \\
\hline &
\end{tabular}

level. EGFSN (2015) highlighted that the chefs and catering assistants comprised of 47,203 employees, representing $29.9 \%$ of hospitality-related employment during 2014. However while figures are given on restaurant, hotel, and catering managers and proprietors, no specific data was available on the number of head chefs employed in the sector.

There is also a $31 \%$ turnover of staff in the Irish hospitality industry (Sheehan, 2014), and Ireland has continued to experience a severe chronic shortage of chefs, forcing employers to source chefs from abroad (MRCI, 2008; RAI, 2013). Irish nationals accounted for $69 \%$ of employees in the sector during 2014. This is lower than the proportion of Irish employees in the wider economy (85\%), signaling the importance of factoring migration into the assessment of possible sources of future skills supply in the hospitality sector. A main skills shortage identified in the EGFSN (2015) report by hospitality businesses was for suitably qualified chefs. Shortages of commis chefs feed into shortages at higher and specialist levels, e.g., demi chef, chef de partie, and pastry chef. The EGFSN (2015) forecasted that between 10,593 and 12,869 new chefs were required to fill future demand from 2015-2020, based on two different scenarios, concluding that if drastic action was not taken in the short to medium term, significant skills shortages were likely to emerge. It is within this Irish context that the current research aims to investigate the factors for success as a head chef in Ireland. 


\section{The head chef}

The organization of the kitchen is usually quite defined by the progression of roles based on seniority using the partie system, which is attributed to Auguste Escoffier (1846-1935). Under this structure, the head chef or chef de cuisine was in charge, assisted by a number of sous chefs and chef de partie, each of which would be in charge of a section in the kitchen and would have a number of commis chefs or apprentices working with them. In a large hotel, the head chef could be in charge of up to 100 staff, whereas in a small restaurant, they might only have two or three other chefs in the kitchen (Taylor \& Taylor, 1990).

Harrington (2005) sees the head chef as CEO and team members as the board of directors in a business, which is the kitchen. Additionally, Fine (1996) uses images of a professional, an artist, a business man, a manual laborer, a craftsperson, a scientist, a humanist, and a philosopher, thus showing the multifaceted roles that a head chef must possess. A detailed profile of the average head chef has also recently been documented (Allen \& Mac Con Iomaire, 2016), which shows the background and demographics of what the average head chef is like. However, most managers rise through the ranks in the workplace (Jauhari, 2006), and many head chefs will have entered their profession at the bottom and worked their way up the occupational ladder (Berta, 2003; Hertzman \& Maas, 2012). Balazs (2002) studied three-star Michelin chefs in France and found that they were extremely charismatic and attracted loyalty from their team, which was willing to work long hours, often for little or no pay, to feel part of something special. While there is a rising trend for attaining third level education (Allen \& Mac Con Iomaire, 2016; Goyette, 2008), Mac Con Iomaire (2008) noted how in a UK context, Heston Blumenthal and Raymond Blanc achieved culinary greatness without following the traditional apprenticeship or college training. This diversity of training background was also evident in a New York study (Parkhurst Ferguson \& Zukin, 1998). However, these individuals and others like Gordon Ramsay possessed such drive, determination, and hard work that they succeeded. Head chefs then merit special attention since they are in a better position than other members of a kitchen brigade to understand what it takes to succeed and progress within the culinary world, having already attained this advancement.

\section{Defining career success}

Career success can be viewed as the "positive psychological or work related outcomes or achievements one has accumulated as a result of one's work experiences" (Judge, Cable, Boudreau, \& Bretz, 1995, p. 486). In general, career success is defined by two broad measures, objective career success and subjective career success. Objective career success involves the observable, 
measurable, and verifiable attainments such as pay, promotion, occupational status, and skill acquisition or competencies (Dries et al., 2008; Johnston \& Phelan, 2016). Nicholson and De Waal-Andrews (2005) outlined six objective success outcomes as being status, material success, social reputation and prestige, knowledge and skills, networks, and health/well being. Subjective career success involves a person's own perception of his accomplishments or self-efficacy, professionalism, future prospects, and sense of career satisfaction (Dries et al., 2008; Johnston \& Phelan, 2016). It is more a measure of how an individual assesses his own personal meaning of career success for themselves (Arthur et al., 2005). Nicholson and De Waal-Andrews (2005) outlined six subjective success outcomes as pride in achievement, job satisfaction, self worth, commitment to work, fulfilling relationships, and moral satisfaction. Arthur et al. (2005) proposed that both objective and subjective career success are interdependent, and therefore in this current study, we have aimed to include both measures of career success as the literature demonstrates.

\section{Competency models}

Many studies that have looked at factors influencing career success also use competency models, first developed by Katz (1955) and then Sandwith (1993). An individual's competency denotes the "ability to respond to the demands placed on them by [his] environment" (Bueno \& Tubbs, 2004, p. 80).

Bueno and Tubbs (2004) interviewed 40 business leaders with international experience and outlined six global leadership competencies. Dries et al. (2008) interviewed 22 managers from banking, food, medical, metal, and tobacco industries and proposed that there were nine regions of career success. However, in developing a competency model, Sandwith (1993) argued that any organization using a competency model would have to adapt it to competencies that are relevant for that particular business.

Whilst a wide variety of data exists on the broader hospitality and tourism industry (Agut, Grau, \& Peiro, 2003; Chung-Herrera et al., 2003; Jauhari, 2006; Akrivos, Ladkin, \& Reklitis, 2007; Wang et al., 2011), specific research on the culinary world remains proportionally underrepresented. Only four journal articles that examined competencies for success of chefs could be found from database searches (Balazs, 2001, 2002; Birdir \& Pearson, 2000; Zopiatis, 2010). The range of variables contributing to success varied greatly between studies, and therefore a broader search in the literature was carried out to identify all the possible variables associated with culinary career success.

\section{Technical skills}

Lee-Ross (2001) has proposed that the job of a chef is very technical where one is required to work with speed and accuracy under imposed time 
constraints. Strong practical culinary skills are therefore very important in the role of a chef (Antun \& Salazar, 2005; Birdir \& Pearson, 2000; Zopiatis \& Constanti, 2007). These skills may be acquired through education and training or through on the job work experience. The lack of cooking skills is something that has been mentioned as to the state of culinary affairs in the UK, which in itself highlights their importance (Caraher, 2012). Along with practical culinary skills, Zopiatis (2010) has outlined that a knowledge of culinary flavors, recipe and menu development, food safety systems and law (e.g. HACCP), food service operations, and keeping up to date with current international trends are all part of the technical skills required by a chef.

\section{Cognitive skills}

Ko (2012) found a significant positive correlation between professional culinary competence and effective learning. This study highlights the importance of general mental abilities and cognitive skills such as critical thinking. It has generally been found that having greater cognitive skills or general mental ability leads to greater career success (Antun \& Salazar, 2005; Dreher \& Bretz, 1991; Judge et al., 1999; Melamed, 1996). One study by Jepsen \& Dickson (2003) even found that cognitive career exploration and early cognitive coping success predicted later success in life.

However, no matter what a person's cognitive ability, having received a good education also aids later success. Despite arguing the case for not going to college, Steinberg (2010) concedes that people who have a college education usually earn more and have less risk of unemployment. Judge et al. (1995) also found that people who had gained a large amount of objective career success generally had impressive education credentials. There is also an increasing trend within the food service industry for those working in the field to attain degrees (Allen \& Mac Con Iomaire, 2016; Goyette, 2008).

Education within college is not the only form that is available. On the job training is one of the factors that is listed by Wang et al. (2011) for career success. Le Vine (2007) also advocates the advantages of continuous training for chefs. The aim of training is to improve knowledge, skills, and attitudes to develop new competencies and thus benefit job performance (Agut et al., 2003). Getz (1994) even found that the absence of training made a job more undesirable to potential employees. Therefore training is an important part of the development of career success for an individual (Dreher \& Bretz, 1991).

\section{Creativity}

Research has demonstrated that there is an increasing demand for creativity within the culinary trade (Caraher, 2012). Indeed Robinson and Barron (2007) have listed creativity as one of the defining features of chef culture. In another study by Robinson and Beesley (2010), they propose that creativity is essential for the success of an organization, as it needs to adapt and change in response 
to an ever-changing market environment. Some dimensions of culinary innovation include the artistic aspiration, learning and networking, adaption and diffusion, perceived newness, and change, with continuous and discontinuous change (Stierand \& Lynch, 2008). Those with higher levels of creativity also usually are more intrinsically motivated for their work (Wong \& Ladkin, 2008).

Despite claims for the essential nature of creativity, $\mathrm{Hu}$ (2010) found that creativity was ranked the second least important core competency in innovative culinary development. In another study by Zopiatis (2010) into the core competencies of chefs in Cyprus, it was also found that the least important ranked competency was creativity. Therefore questions remain to the importance of creativity.

\section{Business skills}

Gilbert and Guerrier (1997) noticed a new trend beginning to emerge where there was a shift from an operational to a business focus in managers. This involved a new emphasis to reach financial targets, save on costs, and use technology to reduce labor time. Raybould and Wilkins (2005) also noted a decreasing importance in operational and technical skills with an increase in emphasis on corporate and strategic skills in the hospitality industry. Strategy and strategic decision making is seen as important at the position of CEO and at the top management level (Harrington, 2005). The rise of business skills in importance (Ladkin, 2000) and also the advantage of strong entrepreneurial skills (Mac Con Iomaire, 2008) have brought with them a focus also on managerial skills.

\section{Managerial skills}

While there may have been a shift away from technical skills towards more business skills in the preceding couple of decades, Ladkin (2000) has also noted a shifting emphasis from craft to managerial skills training, although Birdir and Pearson (2000) noted that some chefs are more focused on the technical skills and others more on management. This has perhaps evolved because of the demand from industry for individuals who are able to solve problems, make decisions, resolve conflict and negotiate, co-operate with others, and listen actively (Steinberg, 2010). Both Agut et al. (2003) and $\mathrm{Hu}$ (2010) have differentiated between two core managerial competencies, and these are technical managerial competencies and generic managerial competencies. Ideally leaders within the kitchen have strong practical skills and "soft" people management skills (Zopiatis \& Constanti, 2007). While management encompasses leadership with skills and with the people working alongside them, it also involves meeting the need of the company to conform to regulations and legislation (Gilbert \& Guerrier, 1997). 


\section{Motivational skills}

Zetie, Sparrow, Woodfield, and Kilmartin (1994) saw the role of management as creating the environment where everyone can enjoy his work, thus highlighting also the motivational skills needed in leaders within the kitchen environment. People need to get along to boost the bottom line of a company (Amer, 2005), and motivating people to work together and resolve conflicts is part of the job of a manager. Along with being able to motivate others, those who lead in the kitchen have to be able to motivate themselves (Zopiatis \& Constanti, 2007) and have a sense of self-efficacy (Antun \& Salazar, 2005). Another way of expressing this could be the sense of professionalism that an individual incorporates into his job (Zopiatis, 2010). Research reports on those who have succeeded within the culinary world have also noted the "gritty determination, obsession and tenacity" (Mac Con Iomaire, 2008, p. 55) that they possess. This ability to persevere and work hard (Dreher \& Bretz, 1991) defines those who have succeeded within the culinary workplace. Indeed, Pratten (2003) noted that the formula for success from his study was having gone to college and entered the work force at the bottom, many head chefs work their way up through the ranks (e.g. Berta, 2003). Therefore, in addition to the determination to succeed and work for it, there is also a need to be passionate about the job (Parseghian, 1995). Wang et al. (2011) have also named the ability to be passionate about the job as taking "work pleasure."

One final point to consider in motivating an individual to succeed is the role of having a mentor. Aryee and Chay (1994) found that having a mentor resulted in more job involvement, more organizational commitment, and increased job satisfaction. Joiner, Baartram, and Garreffa (2004) and Bozionelos (2008) also found that having a mentor increases perceived career success. However, even having a network of support, be that informal friendships (Bozionelos, 2008; Iverson \& Deery, 1997) or the support of a spouse (Judge et al., 1995) or the wider family (Wang et al., 2011) at home, increases the career success of an individual.

\section{Environmental factors}

Wang et al. (2011) demonstrated that it is not just the internal competencies of an individual that enables them to succeed; there is also an interaction with the environment or context in which that individual is placed. In order for a person to succeed at his place of work, there must be a good person-job fit (Judge et al., 1999). Other factors include how the size of a person's salary was related to the size of the place in which they worked (Melamed, 1996; Seibert \& Kraimer, 2001). Another study found that an employee's position within a company affected his level of career satisfaction ( $\mathrm{Tu}$, Forret, \& Sullivan, 2006). Iverson and Deery (1997) found that routinization, role 
conflict, promotion opportunities, and a negative work atmosphere all affected job satisfaction. Mobility possibilities and dynamics of the current job have also been significantly related to subjective career success (Hui, 1988; Iverson \& Deery, 1997; Kuijpers, Schyns, \& Scheerens, 2006). Therefore variables measured in the current study have been broadened to include contextual or environmental factors that influence culinary success.

\section{Personality factors}

While the models developed by Katz (1955) and Sandwith (1993) both included interpersonal or human competencies, the personality of the individual was not fully considered since it is not a competency. The literature shows that personality plays a role in mediating the individual's perceptions about his own career success (Judge et al., 1999; Melamed, 1996; Seibert \& Kraimer, 2001; Wu et al., 2008). These studies show that conscientiousness, extraversion, positivity, independence, and confidence are traits that aid career success while neuroticism and openness are barriers.

Other personality factors or attitudes found to have an influence on career success include a sense of self-efficacy (Antun \& Salazar, 2005; Johnston \& Phelan, 2016), a protean career attitude (De Vos \& Soens, 2008), an ability to persevere and work hard (Dreher \& Bretz, 1991), and passion or "work pleasure" (Wang et al., 2011). Therefore this study developed a theoretical framework that was broad enough to take account of competencies, environmental factors, and personality factors in order to examine what it takes to succeed as a chef.

\section{Demographic factors}

\section{Gender}

Different studies in different cultures have found varying results of the impact of gender on career success. In general, white Western males had higher levels of objective career success (Judge et al., 1995; Melamed, 1996). However, a Chinese study found that women had higher total compensation (Tu et al., 2006), while another study by Seibert and Kraimer (2001) found a non-significant relationship of gender and salary. However an interesting study by Valcour and Ladge (2008) found that among women, those who began childbearing at relatively older ages, those who had fewer children, and those whose childbearing commenced longer ago earned higher incomes. There is also a mixed bag of results in regard to subjective career success, with $\mathrm{Ng}$ and Pine (2003) only reporting gender differences on 3 of 14 factors that they investigated. While Hofmans, Dries, and Pepermans (2008) reported that men gave higher ratings of career satisfaction than women on almost all ratings of questionnaire items. Therefore it would be interesting to see the effects of gender on ratings in an Irish context. 


\section{Age}

Generally the literature seems to suggest higher ratings of subjective career success with increasing age (Hertzman \& Maas, 2012; Tu et al., 2006). Gursoy, Maier, and Chi (2008) offered an interesting explanation where they suggest that older generations are more willing to wait their turn rather than expect immediate recognition of the younger generations. Other studies have also proposed that differences in expectations, values, attitudes, and behavior between generational cohorts may be explained by the different cultures prevalent in society at different eras in time (Davidson, McPhail, \& Barry, 2011; Lub, Bijvank, Bal, Blomme, \& Schalk, 2012).

\section{Perceptions of success}

Having examined the literature to find the variables that would influence the career success of a head chef, it was considered how to measure these variables. The format used by Zopiatis (2010) seemed effective, where chefs rated each of the variables on a scale both for importance and also for the level of development personally, and this was the outline used in the current study. By using these two scales of measures, it can be determined if opinions about what is important to succeed actually match the performance and personal ownership of these variables in head chefs or where differences lie. Hansson (2001) questioned the reliability of self-estimates, as it is suggested that they lack the objectivity of a neutral bystander. Indeed, Gunz and Heslin (2005) also suggested that participants may not portray their situation honestly but inadvertently introduce some bias. Therefore a number of internal measures were introduced that measured the same variable in the two sections of the questionnaire and then could be statistically checked that responses matched.

\section{Research question 1 (RQ1)}

What are the objective and subjective measures of success for head chefs working in Ireland?

\section{Research question 2 (RQ2)}

How do head chefs rate the importance of the variables needed to succeed within the Irish culinary context? And how do they rate themselves on personal ownership of these variables?

\section{Research question 3 (RQ3)}

How do perceptions of the variables needed for success (NS) and personal ownership (PO) of these variables compare and are there any significant differences? 


\section{Research question 4 (RQ4)}

Can the variables for success be grouped together to show the factors needed for career success within the culinary industry?

\section{Methodology}

\section{Research instrument}

A new questionnaire was devised that followed the format of Zopiatis (2010) but with the addition of some more variables to include competencies for success, personality factors, and environmental factors. The development of the list of variables used in this study (see Table 2) was based on a review of relevant literature from database searches using the search terms of "competencies," "success," and "chef".

The variables are listed in alphabetical order as per the study by Zopiatis (2010) and rated on both needed for success (NS) and personal ownership (PO) scales. Each variable was rated on an Osgood semantic differential rating scale (Osgood, 1964) with seven points rather than the five-point Likert rating scale used by Zopiatis (2010) to avoid central tendency error and to increase the validity of data. The current study also expanded the demographics section used by Zopiatis (2010) to include further detailed measures of the background of head chefs and also measures of both objective and subjective success based on points mentioned in the literature review. An overview of the 19 questions on demographics and success measures is presented in the results section with their findings (Table 3 ).

\section{Sampling method}

A pilot test of the questionnaire was carried out with 10 participant head chefs recruited through a mixture of personal contacts and emails to local establishments. Following this only a few minor adjustments to the questionnaire with wordings and typographical errors were made. The final question from the pilot study asked if anything was unclear or could be improved and was then dropped in the main study. Scale reliability of the pilot test had an alpha coefficient of 0.96, which shows a very high degree of reliability (De Vaus, 1993). Since there were no major changes after the pilot study, these 10 responses were included in the overall findings of the main study.

Table 3. Importance performance grid.

\begin{tabular}{ll}
\hline Possible Overkill Quadrant & Low Priority Quadrant \\
Low Importance & Low Importance \\
High Performance & Low Performance \\
Keep up the Good Work Quadrant & Concentrate Here Quadrant \\
High Importance & High Importance \\
High Performance & Low Performance \\
\hline
\end{tabular}


In obtaining the population sample of head chefs, two official bodies, the Restaurants Association of Ireland (RAI) and the Irish Hotels Federation (IHF), were contacted, informed as to the nature of the research, asked for their endorsement and access to their databases of contacts. Two sponsored prizes from food businesses were secured to increase response rates (Oppenheim, 1992). Cover letters were then drawn up that introduced the study, mentioned endorsement of trade bodies, and offered the incentive of a prize-draw for all completed questionnaires (De Vaus, 1993).

Due to the high costs of sending a postal questionnaire, it was decided to send the questionnaire via e-mail, along with a cover letter. E-mails were sent to head chefs all around the Republic of Ireland, a follow-up e-mail was sent two weeks later, and a final e-mail three weeks after to remind participants that the closing date for responses was soon due.

There was quite a low response rate $(7.47 \%)$ to the e-mailed surveys, 71 returned from about 950 valid addresses. However, a contact was secured from a contract catering firm that runs a number of restaurants in the corporate sector and the survey was sent internally to all 70 of its head chefs via e-mail, and 20 of these were returned (28.57\%). To ensure a robust sample size, it was then decided to also personally call in to premises and ask the head chef to fill in the questionnaire and arrange a time to collect the questionnaires. Most of these walk-in collections were in Dublin city but some were also from Wexford, Galway, Sligo, Wicklow, and the greater Dublin region.

\section{Data analysis}

In order to answer each of the research questions, a number of tests and statistics were planned as follows and computed using SPSS, version 22.

\section{Research question 1 (RQ1)}

What are the objective and subjective measures of success for head chefs working in Ireland?

Descriptive statistics including simple frequencies and mean ratings were computed on head chefs' answers in the demographics section. Since the data cannot be assumed to be normally distributed, non-parametric statistics using Chi-squared tests were used to assess how each of the independent variables in the demographics section related to each of the other independent variables in the demographics section in order to assess any interactions.

\section{Research question 2 (RQ2)}

How do head chefs rate the importance of the variables needed to succeed within the Irish culinary context? And how do they rate themselves on personal ownership of these variables? 
Each of the 59 variables was rated by head chefs on a scale of $1-7$, firstly for its perceived importance to success and then secondly on how they rated their own personal ownership of these variables. Following the method used by Zopiatis (2010), mean ratings for scores on each of the variables on each of the scales were computed and then ranked in order.

\section{Research question 3 (RQ3)}

How do perceptions of the variables NS and PO of these variables compare and are there any significant differences?

Importance-performance analysis (Martilla \& James, 1977) following the format used by Zopiatis (2010) was used to analyze results in comparing ratings on each of the scales. This test uses the median values of scores given for each variable on each of the two scales and plots them on a two-dimensional grid for performance (PO scale) on the $\mathrm{x}$-axis and importance (NS scale) on the $\mathrm{y}$-axis (see Table 3). High importance and high performance ratings given by the head chefs are denoted by low values on the scales (i.e., closer to 1) while low importance and low performance ratings are denoted by higher values on the scales (i.e., closer to 3). The intersection of the axes in the analysis is determined by obtaining the midpoint (or mean) of all of the median values on each of the scales. The resulting graph highlights where results show "to concentrate," "where to keep up the good work," which results have "low priority," and those that may have "possible overkill."

\section{Research question 4 (RQ4)}

Can the variables for success be grouped together to show the factors needed for career success within the culinary industry?

Factor analysis was planned to assess whether variables on each of the scales could be summarized into key areas.

\section{Results}

\section{Demographics}

One-hundred and seventy head chefs from around the Republic of Ireland completed the survey. Table 4 shows the demographic profile of the respondents. There were 19 different nationalities represented in the sample, so the data was recoded to having five different areas of the world represented: Ireland, the rest of Europe, Africa, the Americas, and the East (including China, Thailand, Malaysia, Australia, India, and Iran).

\section{Career success}

In order to ascertain answers to RQ1, specific measures on the questionnaire were analyzed and cross-referenced. Figure 1 as follows shows a measure of 
Table 4. Demographics.

\begin{tabular}{|c|c|c|c|c|c|}
\hline Demographic description & Frequency & Percentage & Demographic description & Frequency & Percentage \\
\hline Gender & & & How Data Gathered & & \\
\hline Male & 143 & $84.1 \%$ & Email & 71 & $41.8 \%$ \\
\hline Female & 25 & $14.7 \%$ & Recruited & 20 & $11.8 \%$ \\
\hline Missing & 2 & $1.2 \%$ & Walk In & 79 & $46.5 \%$ \\
\hline Age & & & Wages & & \\
\hline Under 30 & 22 & $13.1 \%$ & Under 20k & 8 & $4.7 \%$ \\
\hline $31-40$ & 82 & $48.8 \%$ & $20-30 k$ & 21 & $12.4 \%$ \\
\hline $41-50$ & 54 & $31.8 \%$ & $30-40 \mathrm{k}$ & 48 & $28.2 \%$ \\
\hline $51-60$ & 9 & $5.3 \%$ & $40-50 \mathrm{k}$ & 32 & $18.8 \%$ \\
\hline $61+$ & 1 & $0.6 \%$ & $50 \mathrm{k}+$ & 38 & $22.4 \%$ \\
\hline Missing & 2 & $1.2 \%$ & Missing & 23 & $13.5 \%$ \\
\hline Nationality & & & Wage Satisfaction & & \\
\hline Irish & 114 & $67 \%$ & Totally Agree & 33 & $19.4 \%$ \\
\hline European & 28 & $16.5 \%$ & Somewhat Agree & 42 & $24.7 \%$ \\
\hline Eastern & 13 & $7.6 \%$ & Neutral & 47 & $27.6 \%$ \\
\hline African & 2 & $1.2 \%$ & Somewhat Disagree & 27 & $15.9 \%$ \\
\hline American & 2 & $1.2 \%$ & Totally Disagree & 15 & $8.8 \%$ \\
\hline Missing & 11 & $6.5 \%$ & Missing & 6 & $3.5 \%$ \\
\hline Marital Status & & & Current Workplace & & \\
\hline Single & 53 & $31.2 \%$ & Hotel & 45 & $26.5 \%$ \\
\hline Married & 89 & $52.4 \%$ & Restaurant & 111 & $65.3 \%$ \\
\hline Divorced & 13 & $7.6 \%$ & Bakery & 7 & $4.1 \%$ \\
\hline Other & 14 & $8.2 \%$ & Missing & 7 & $4.1 \%$ \\
\hline Missing & 1 & $0.6 \%$ & & & \\
\hline Years Working & & & Location & & \\
\hline $0-5$ & 4 & $2.4 \%$ & Connaught & 23 & $13.5 \%$ \\
\hline $6-10$ & 24 & $14.1 \%$ & Ulster & 4 & $2.4 \%$ \\
\hline $11-15$ & 35 & $20.6 \%$ & Munster & 18 & $10.6 \%$ \\
\hline $16-20$ & 37 & $21.8 \%$ & Leinster (except Dublin) & 24 & $14.1 \%$ \\
\hline $21-25$ & 41 & $24.1 \%$ & Dublin & 97 & $57.1 \%$ \\
\hline $26+$ & 28 & $16.5 \%$ & Missing & 4 & $2.4 \%$ \\
\hline Missing & 1 & $0.6 \%$ & & & \\
\hline Job Satisfaction & & & Achievement Felt in Job & & \\
\hline Totally Agree & 65 & $38.2 \%$ & Totally Agree & 85 & $50 \%$ \\
\hline Somewhat Agree & 71 & $41.8 \%$ & Somewhat Agree & 57 & $33.5 \%$ \\
\hline Neutral & 13 & $7.6 \%$ & Neutral & 16 & $9.4 \%$ \\
\hline Somewhat Disagree & 11 & $6.5 \%$ & Somewhat Disagree & 4 & $2.4 \%$ \\
\hline Totally Disagree & 5 & $2.9 \%$ & Totally Disagree & 3 & $1.8 \%$ \\
\hline Missing & 5 & $2.9 \%$ & Missing & 5 & $2.9 \%$ \\
\hline $\begin{array}{l}\text { See Work As } \\
\text { Identity }\end{array}$ & 33 & $19.4 \%$ & $\begin{array}{l}\text { Highest Educational } \\
\text { Achievement }\end{array}$ & & \\
\hline Calling & 7 & $4.1 \%$ & Secondary School & 19 & $11.2 \%$ \\
\hline Means to End & 7 & $4.1 \%$ & Apprenticeship & 32 & $18.8 \%$ \\
\hline Self-Realization & 16 & $9.4 \%$ & FETAC course & 33 & $19.4 \%$ \\
\hline Journey & 77 & $45.3 \%$ & Degree & 60 & $35.3 \%$ \\
\hline Investment of Skills for & 20 & $11.8 \%$ & Master's & 7 & $4.1 \%$ \\
\hline Good Society & & & Other & 15 & $8.8 \%$ \\
\hline Missing & 10 & $5.9 \%$ & Missing & 4 & $2.4 \%$ \\
\hline
\end{tabular}




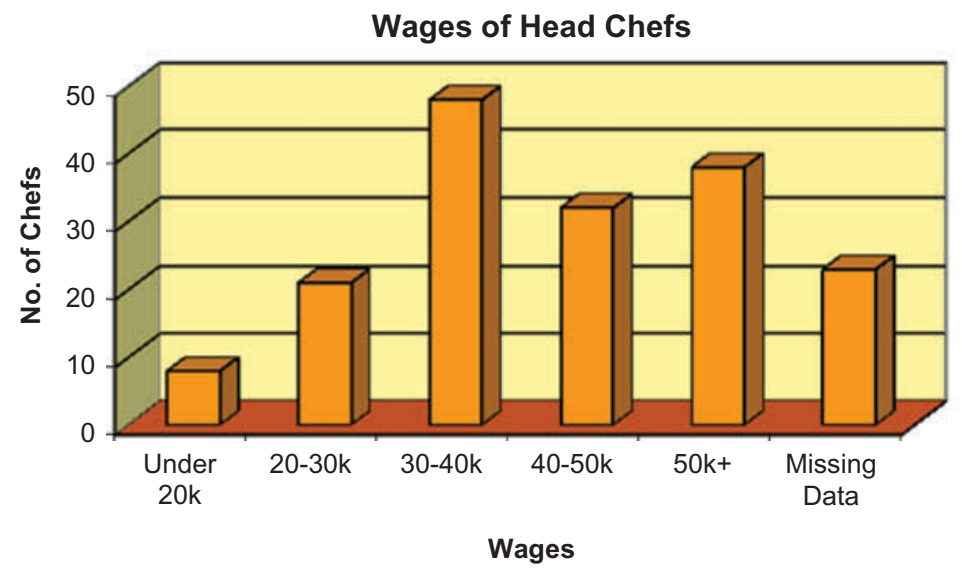

Figure 1. Wages of head chefs.

the objective success of head chefs, namely their wages. The national average wages of head chefs working in Ireland was an income of €30,001-€40,000. However, Figure 2 shows that those who were earning the highest wages were also working the greatest amount of years $\left(\chi^{2}=52.835, \mathrm{df}=20, p=0.00\right)$. Standardized residuals also showed that those observed to earn more than $€ 50 \mathrm{k}$ were significantly more than the expected at 21-25 years.

A measure of the subjective success of head chefs was recorded in their ratings of job satisfaction (see Figure 3). There was a significant relationship $\left(\chi^{2}=45.628, \mathrm{df}=20, p=0.001\right)$ between job satisfaction and years working (see Figure 4). Dissatisfaction was high among those working less than 10 years, with standard residuals for those working less than 5 years at 2.5 for those totally dissatisfied and 3.4 for those somewhat dissatisfied. Standard residuals for those somewhat dissatisfied and working 6-10 years were also of

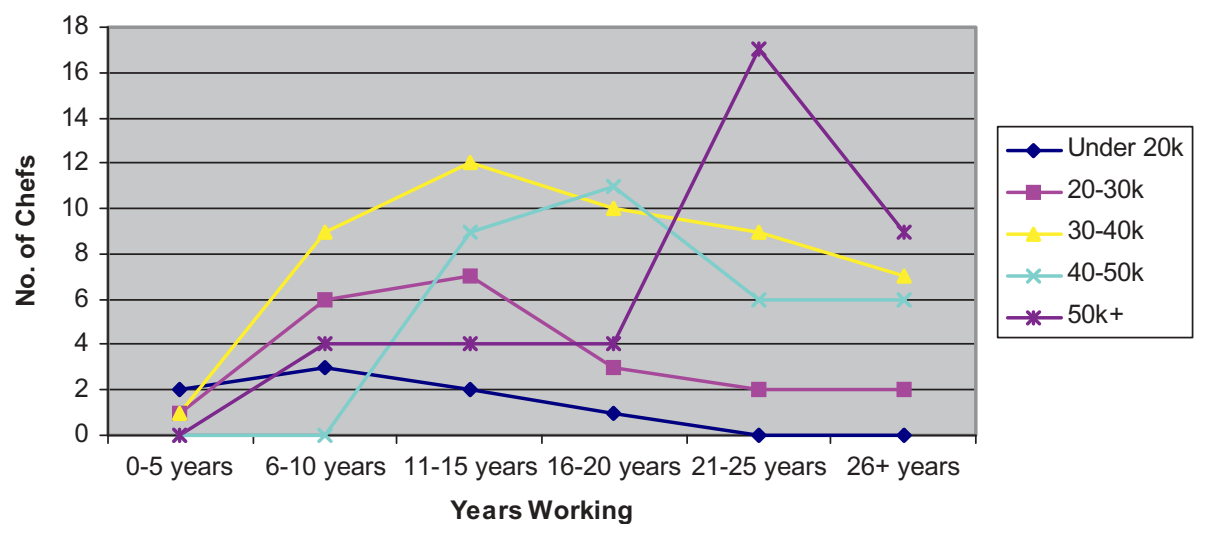

Figure 2. Wages earned by years working. 


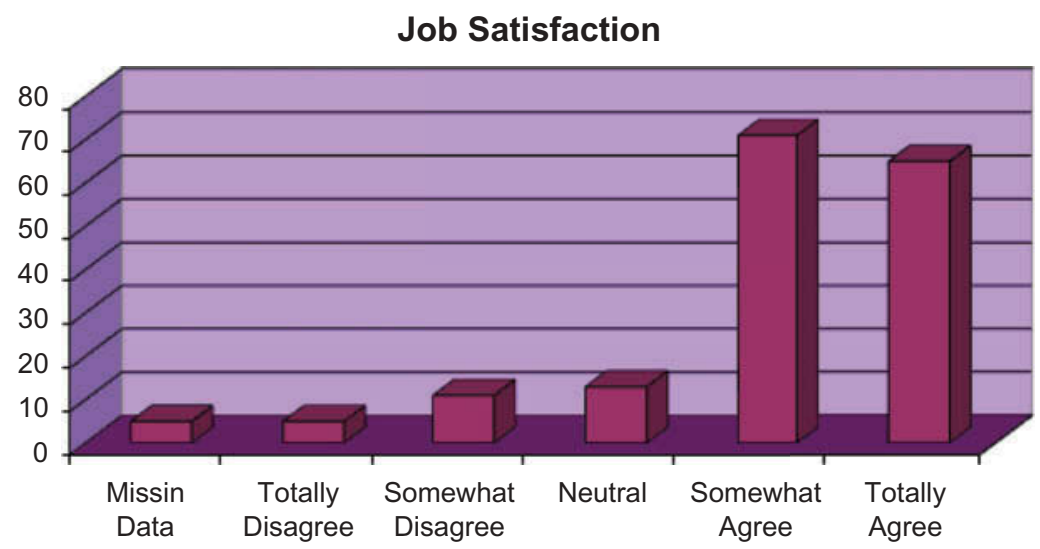

Figure 3. Job satisfaction.

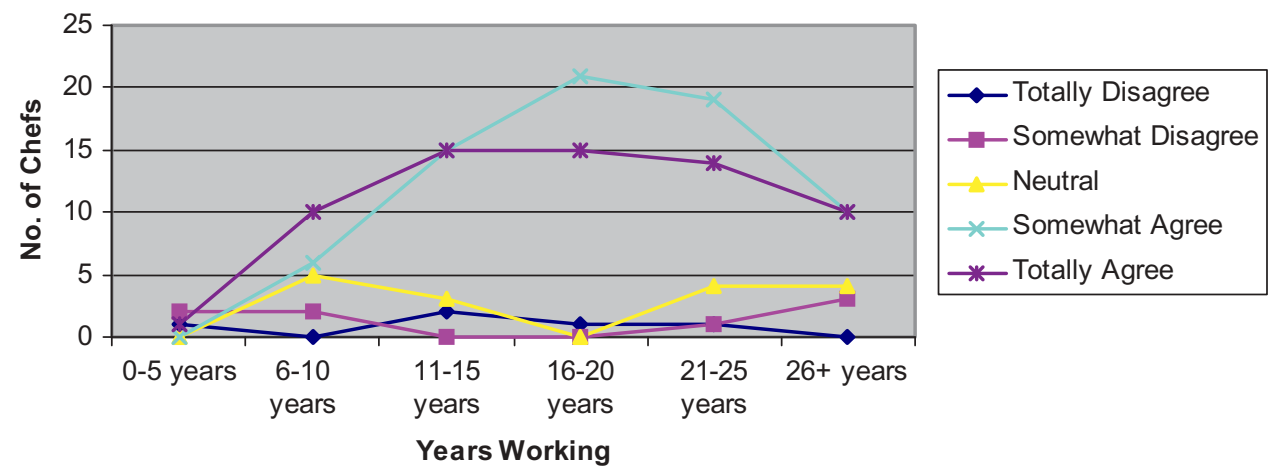

Figure 4. Job satisfaction and years working.

note at 2.8. Therefore this suggests a higher than expected amount of dissatisfaction in the early years of work, however job satisfaction then picks up again long term.

Interestingly, job satisfaction was also significantly related to wages earned $\left(\chi^{2}=30.686, \mathrm{df}=16, p=0.015\right)$, as Figure 5 shows. This graph shows that the majority of head chefs who were earning the highest wages were totally satisfied with their jobs, while those earning less were only somewhat satisfied in their jobs. Standardized residuals for this analysis also showed a higher than expected count of satisfaction ratings that were correlated on both scales. For example those totally dissatisfied, somewhat dissatisfied, neutral, somewhat satisfied, and totally satisfied on both scales was higher than expected in each of these points.

\section{Ratings for variables}

In order to answer RQ2, participants were asked to rate 59 variables on a scale of 1-7 for how important they thought that each one listed was in contributing to the 


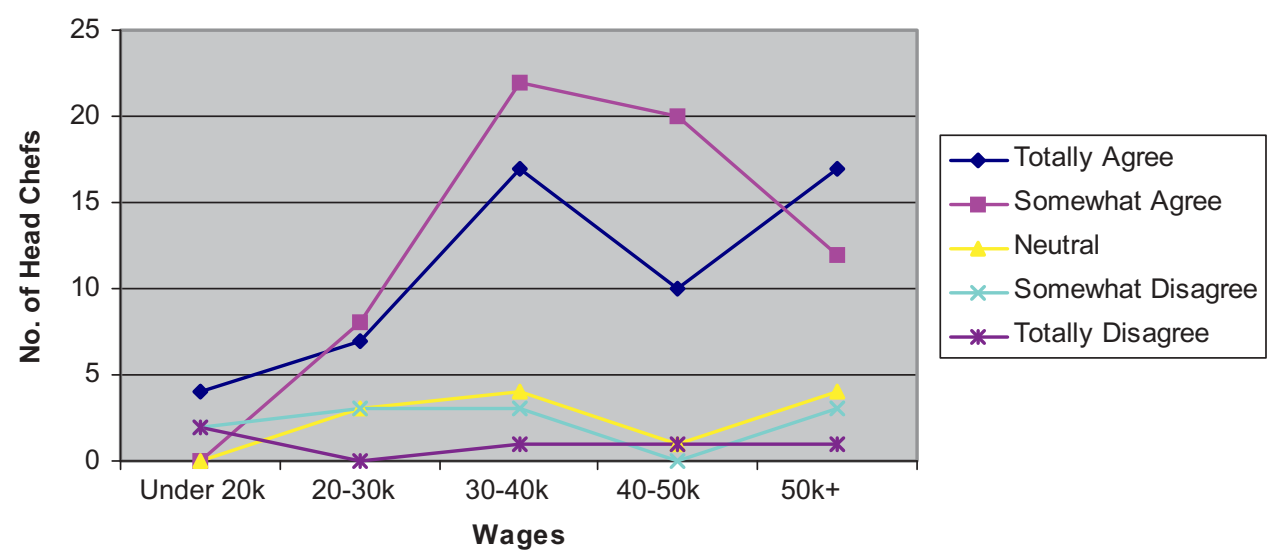

Figure 5. Job satisfaction and wages.

success of a head chef in Ireland. This first scale was a rating of the variables "needed for success" (NS scale). They were also asked then to rate on a scale of 1-7 how much they thought they had personal ownership (PO scale) of each of these listed characteristics. An alpha co-efficient of 0.97 showed the scale to be highly reliable (De Vaus, 1993; Oppenheim, 1992). Figure 6 shows the mean ratings given to each of the 59 variables. Mean ratings for each of the traits on the NS scale were between 1.18 and 3.23, which corresponds to "extremely important" and "moderately important." Thus, even the lowest rated items were still deemed moderately important. Mean ratings for each of the variables on the PO scale were between 1.3 and 2.94, which corresponds to "describes me down to a T" and "yes I have plenty of this trait." Again, the lowest rated items still reflected variables that head chefs perceived themselves as possessing plenty of these traits.

\section{Importance-Performance analysis}

RQ3 involves comparing and contrasting the responses of participant head chefs both on the NS and PO scales. Figure 7 depicts the results of importanceperformance analysis.

It can be seen that variables in the "concentrate here" area of the graph are where head chefs have rated variables as high in importance but have rated their $\mathrm{PO}$ of such variables as lower. Variables highlighted in this section include: confidence, innovation, keeping up with current trends, self-discipline, communication, budgeting, cost management, motivating others, and delegating.

Another quadrant from this analysis shows the areas that head chefs in Ireland can "keep up the good work" that they are already doing. Variables that were rated high in importance but also high in personal ownership included: work hard, knowledge of HACCP, organized, previous experience, perseverance, knowledge of flavors, passion, professionalism, work pleasure, knowledge of menu development, time management, culinary skill, knowledge of profit and loss, 


\begin{tabular}{|c|c|}
\hline Traits Important for Success: & Mean: \\
\hline 1. Commitment to Quality & 1.18 \\
\hline 2. Organised & 1.26 \\
\hline 3. Knowledge of HACCP & 1.337 \\
\hline 4. Ability to work hard & 1.339 \\
\hline 5. Knowledge of flavour & 1.345 \\
\hline 6. Ability to Motivate Self & 1.349 \\
\hline 7. Conscientiousness & 1.41 \\
\hline 8. Professionalism & 1.43 \\
\hline 9. Menu Planning & 1.44 \\
\hline 10. Cost Management & 1.451 \\
\hline 11. Ability to Motivate Others & 1.452 \\
\hline 12. Budgeting & 1.458 \\
\hline 13. Culinary Skill & 1.46 \\
\hline 14. Time Management & 1.473 \\
\hline 15. Work Pleasure & 1.479 \\
\hline 16. Knowledge of Profit and Loss & 1.48 \\
\hline 17. Ability to Delegate & 1.51 \\
\hline 18. Positive A & 1.521 \\
\hline 19. Passion & 1.526 \\
\hline 20. Com & 1.53 \\
\hline 21. Deci & 1.54 \\
\hline 22. Pos & 1.55 \\
\hline 23. Resp & 1.56 \\
\hline 24. Abilit & 1.568 \\
\hline 25. Job $\mathrm{Tl}$ & 1.6 \\
\hline 26. Flex & 1.61 \\
\hline 27. Pers & 1.64 \\
\hline r teamwork & 1.648 \\
\hline 29. Self & 1.66 \\
\hline 30. Prob & 1.68 \\
\hline late with Trends & 1.72 \\
\hline 32. Cont & 1.77 \\
\hline 33. Innov & 1.78 \\
\hline long with Others & 1.8 \\
\hline 35. Prev & 1.82 \\
\hline 36. Ope & 1.87 \\
\hline 37. Per & 1.89 \\
\hline 38. Dea & 1.91 \\
\hline 39. Com & 1.92 \\
\hline 40. Critic & 1.95 \\
\hline 41. Con & 1.97 \\
\hline 42. Em & 1.98 \\
\hline in in the Job & 2 \\
\hline 44. Opportunity to Progress & 2.01 \\
\hline 45. Planning & 2.09 \\
\hline 46. Internalisation of Company Objs & is 2.12 \\
\hline 47. Care & 2.15 \\
\hline 48. Hay & 2.3 \\
\hline 49. Fam & 2.33 \\
\hline 50. Sens & 2.34 \\
\hline 51. Career Plan & 2.37 \\
\hline 52. Phys & 2.41 \\
\hline 53. Tim & 2.5 \\
\hline 54. Education & 2.53 \\
\hline 55. Agreeable & 2.58 \\
\hline 56. Other Job Ops in Market & 2.66 \\
\hline 57. Extroverted & 2.79 \\
\hline 58. Netv & 2.92 \\
\hline 59. Computer Skills & 3.23 \\
\hline
\end{tabular}

\section{Personal Ownership of Traits:}

1. Ability to Work Hard

2. Commitment to Quality

3. Knowledge of HACCP

4. Menu Planning

5. Knowledge of Flavour

6. Work Pleasure

7. Passion

8. Professionalism

9. Perseverance

10. Conscientiousness

11. Organised

12. Respect for Others

13. Positive Attitude

14. Culinary Skill

15. Knowledge of Profit and Loss

16. Previous Experience

17. Flexibility

18. Decision Making

19. Ability to Adapt

20. Time Management

21. Problem Solving

22. Ability to Motivate Self

23. Positive Atmosphere

24. Fostering Teamwork

25. Ability to Get Along with Others 1.81

26. Company Commitment 1.82

27. Person-Job Fit $\quad 1.89$

28. Dealing with Change $\quad 1.89$

29. Open Minded 1.9

30. Job Training 1.902

31. Desire to Remain in the Job $\quad 1.907$

32. Cost Management $\quad 1.91$

33. Budgeting 1.92

34. Communication $\quad 1.93$

35. Opportunity to Progress $\quad 1.95$

36. Keeping up to date with Trends 1.957

37. Self Discipline $\quad 1.963$

38. Innovation $\quad 1.963$

39. Confidence 1.97

40. Ability to Delegate 2.03

41. Company Satisfaction 2.031

42. Ability to Motivate Others $\quad 2.036$

43. Education 2.073

44. Critical Thinking 2.074

45. Length of Time with Employer 2.08

46. Emotional Control 2.09

47. Family Support 2.09

48. Careful 2.193

49. Planning 2.198

50. Internalisation of Company Objs. 2.22

51. Sensitivity 2.25

52. Physical Fitness 2.3

53. Extroverted 2.46

54. Agreeable 2.49

55. Career Planning $\quad 2.54$

56. Having a Mentor $\quad 2.62$

57. Other Job Ops in Market 2.7

58. Computer Skills 2.93

59. Networking 2.94

Figure 6. Ratings for variables on each scale. 


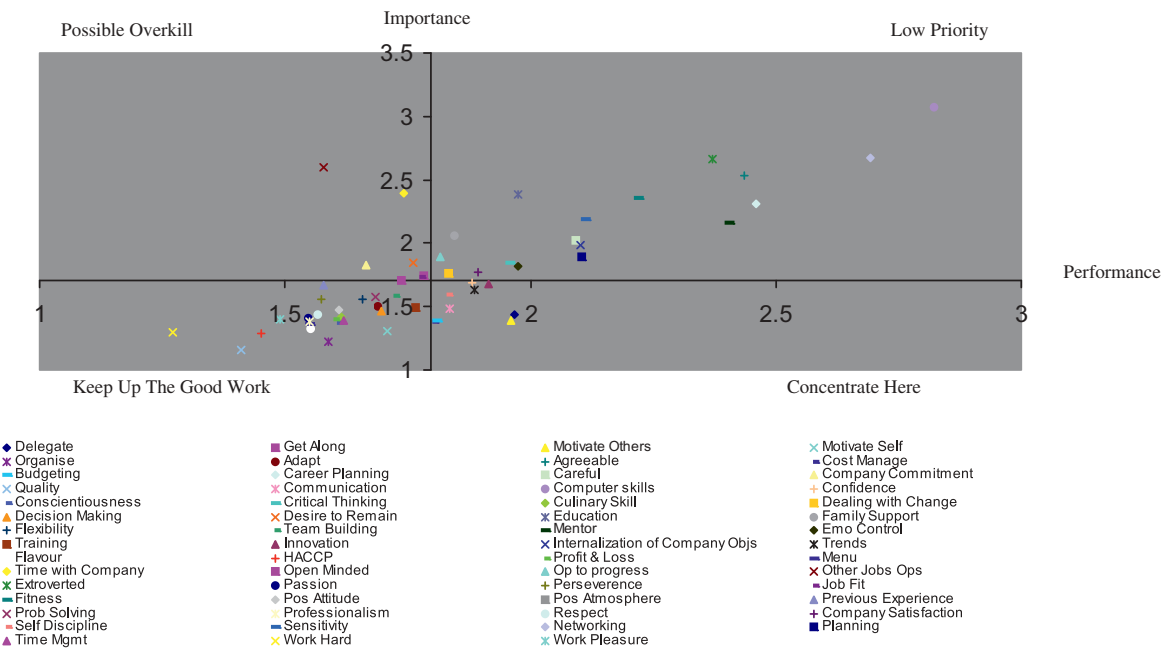

Figure 7. Importance-Performance analysis.

conscientiousness, respect, flexibility, positive work atmosphere, able to motivate self, decision making, able to adapt, problem solving, team building, training, able to get along, commitment to quality, and a positive attitude.

Variables that were considered of "low priority," where they were rated both lower in importance and also low in PO, included: dealing with change, opportunity to progress in the company, family support, company satisfaction, critical thinking, emotional control, strategic planning, internalizing company objectives, carefulness, physical fitness, sensitivity, education, having a mentor, career planning, agreeableness, being extroverted, networking, and having computer skills.

And finally, variables that were rated higher in PO than considered in importance for success, which fall in the "possible overkill" quadrant, included: having other job opportunities, length of time with their current employer, desire to remain in the job, person-job fit, company commitment, and open mindedness. These variables do not pose issues for head chefs working in Ireland. It is important to note that even the lowest variables were rated as moderately important.

\section{How demographics affected ratings}

Each of the 19 demographic independent variables was cross-referenced with the scoring for each of the success scales that head chefs rated. There were 147 significant relationships between the demographics and how head chefs rated each of the 59 characteristics that they thought were needed for success. Similarly there were 158 significant relationships between the demographics and how head chefs rated PO of the listed characteristics on the success scale. The most significant independent variable was that of "work perspective." Nationality was the independent variable that most affected how ratings on the PO scale 
were distributed. Age, years working, number of previous jobs, wages earned, job satisfaction, education, achievement felt in current job, marital status, gender, and how the data was gathered all showed interaction with how variables were rated on each of the scales. However, a detailed breakdown of these findings is outside the scope of this article but may form the substance of a separate article.

\section{Factor analysis}

The final aim of this research (RQ4) was to see if a model could be constructed that would summarize all the factors for success as a head chef, combining competencies, personality, and environmental variables. In this regard, factor analysis was carried out on both the NS and PO scales to see if variables could be grouped together under common themes. Therefore the 59 variables listed for both the NS scale and the PO scale were subjected to principal components analysis (PCA) using SPSS, version 22. The Kaiser-Meyer-Olkin (KMO) value for the NS scale was 0.84 and for the PO scale 0.874, exceeding the recommended value of 0.7 (De Vaus, 1993) for scales suitable for factor analysis. Bartlett's test of sphericity reached statistical significance for both the NS scale $\left(\chi^{2}=5093.932, \mathrm{df}=1653, p=0.000\right)$ and the PO scale $\left(\chi^{2}=5436.88, \mathrm{df}=1770\right.$, $p=0.000)$ also, supporting the factorability of the correlation matrix.

\section{NS scale}

PCA revealed the presence of 15 components with eigenvalues exceeding 1 , explaining $68.7 \%$ of the variance. An inspection of the scree plot (see Figure 8 ) revealed a leveling out effect after the third component. Varimax rotation was performed and the rotated solution revealed a number of medium strength loadings that explained $14.95 \%, 12.36 \%$, and $10.57 \%$ of the variance, respectively. Each of the characteristic groupings could be summarized as comprising of the three factors of professionalism, leadership skills, and interaction with job context (see Table 5).

Factor 1 -Professionalism: (average mean $=1.533$, average rank $=18.2$ )

Factor 2-Leadership Skills: (average mean $=1.658$, average rank $=24.2$ )

Factor 3-Interaction with Job Context: (average mean $=2.187$, average rank $=43.96)$

\section{PO scale}

PCA revealed the presence of 15 components with eigenvalues exceeding 1, explaining $70 \%$ of the variance. An inspection of the scree plot revealed a leveling out effect after the fifth component (see Figure 9). In the interpretation of these five components, Varimax rotation was performed. The rotated solution revealed a number of medium strength loadings that explained $12.99 \%, 10.98 \%, 10.47 \%, 7.81 \%$, and $7.62 \%$ of the variance, respectively. On examination of the five components, it was noted that each of the 


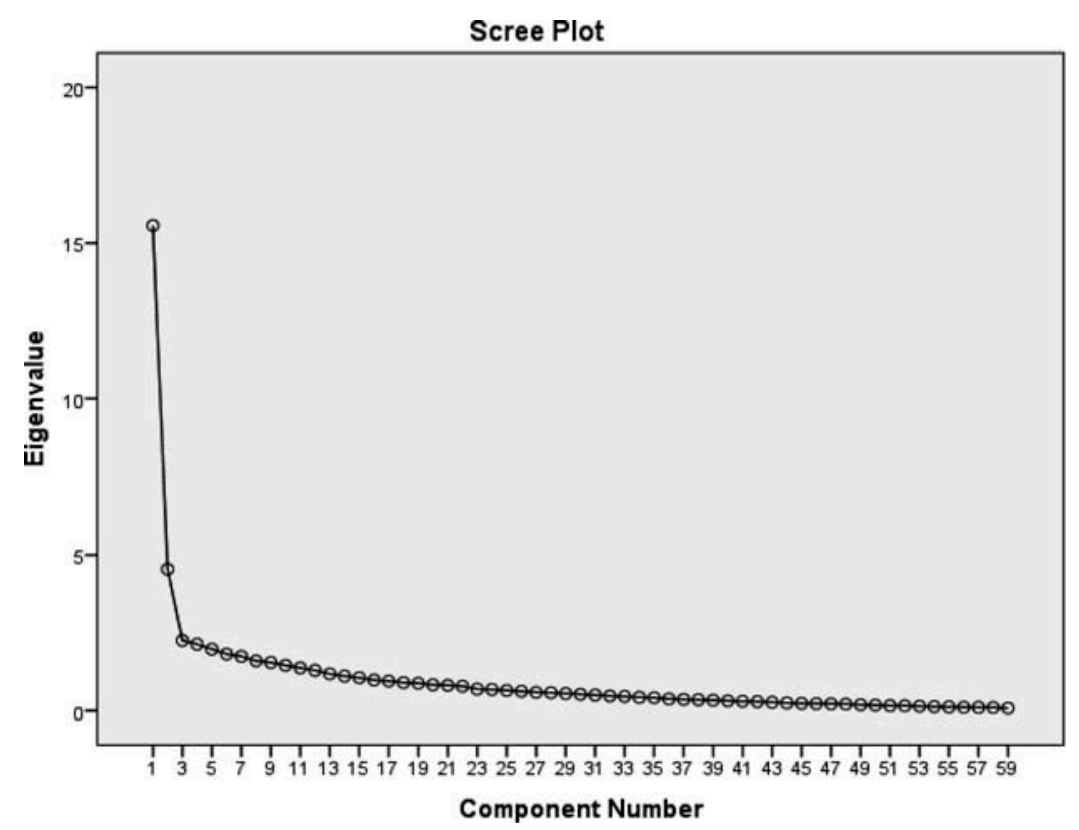

Figure 8. Scree plot for NS scale.

characteristic groupings could be summarized as comprising of the factors as outlined in the following. Details of component characteristics for each factor are indicated on Table 6.

Factor 1 -Professionalism: (average mean $=1.8$, average rank $=22.39$ )

Factor 2-Individual Characteristics: (average mean $=1.846$, average rank $=26.17)$

Factor 3-Management Skills: (average mean $=1.836$, average rank $=30.07$ )

Factor 4-Leadership Skills: (average mean $=1.944$, average rank $=29.21$ )

Factor 5-Interaction with Job Environment: (average mean $=2.13$, average rank $=38.91)$

\section{Discussion}

\section{Main findings on career success}

The first objective of the current study was to investigate the measures of success for head chefs working in Ireland. One objective measure of success found that on average, head chefs working in Ireland were earning between $€ 30,000-€ 40,000$ per annum. These figures correspond to the average industrial wage in Ireland (MRCI, 2008). Therefore, the highest achievers in the culinary world are only earning the equivalent of mid-level workers in the industrial sector. A frequent complaint about the culinary industry is the low pay (Collins, 2001; Hertzman \& Maas, 2012; Iverson \& Deery, 1997; Mac Con Iomaire, 2008; Pratten, 2003; Wang et al., 2011). Results from the 
Table 5. Factor analysis of variables needed for success.

\begin{tabular}{|c|c|c|c|c|c|}
\hline 1. Professionalism & $\begin{array}{l}\text { Correlational } \\
\text { value }\end{array}$ & $\begin{array}{l}\text { 2. Leadership } \\
\text { skills }\end{array}$ & $\begin{array}{c}\text { Correlational } \\
\text { value }\end{array}$ & $\begin{array}{l}\text { 3. Interaction } \\
\text { with job context }\end{array}$ & $\begin{array}{l}\text { Correlational } \\
\text { value }\end{array}$ \\
\hline Organize & 0.699 & $\begin{array}{l}\text { Commitment to } \\
\text { Quality }\end{array}$ & 0.325 & Work Pleasure & 0.312 \\
\hline Adapt & 0.685 & Works Hard & 0.347 & Sensitivity & 0.716 \\
\hline Conscientious & 0.682 & Decision Making & 0.384 & Physical Fitness & 0.655 \\
\hline Communication & 0.654 & $\begin{array}{l}\text { Time } \\
\text { Management }\end{array}$ & 0.417 & Computer Skills & 0.645 \\
\hline $\begin{array}{l}\text { Quality } \\
\text { Commitment }\end{array}$ & 0.649 & $\begin{array}{l}\text { Ability to } \\
\text { Delegate }\end{array}$ & 0.37 & $\begin{array}{l}\text { Time with } \\
\text { Company }\end{array}$ & 0.614 \\
\hline Work Hard & 0.64 & Problem Solving & 0.342 & Education & 0.597 \\
\hline Motivate Self & 0.634 & Knows Flavors & 0.336 & Extroverted & 0.596 \\
\hline Team Building & 0.602 & $\begin{array}{l}\text { Time with } \\
\text { Company }\end{array}$ & 0.369 & Career Planning & 0.588 \\
\hline Motivate Others & 0.572 & $\begin{array}{l}\text { Internaliaation of } \\
\text { Company Objs. }\end{array}$ & 0.422 & Networking & 0.581 \\
\hline Decision Making & 0.557 & $\begin{array}{l}\text { Company } \\
\text { Commitment }\end{array}$ & 0.386 & $\begin{array}{l}\text { Internaliaation of } \\
\text { Company Objs. }\end{array}$ & 0.572 \\
\hline Confidence & 0.537 & $\begin{array}{l}\text { Company } \\
\text { Satisfaction }\end{array}$ & 0.411 & Agreeable & 0.557 \\
\hline Culinary Skill & 0.535 & $\begin{array}{l}\text { Opportunity to } \\
\text { Progress }\end{array}$ & 0.702 & $\begin{array}{l}\text { Company } \\
\text { Commitment }\end{array}$ & 0.555 \\
\hline Cost Management & 0.52 & $\begin{array}{l}\text { Know Menu } \\
\text { Development }\end{array}$ & 0.686 & $\begin{array}{l}\text { Company } \\
\text { Satisfaction }\end{array}$ & 0.516 \\
\hline Flexibility & 0.513 & Know HACCP & 0.61 & $\begin{array}{l}\text { Emotional } \\
\text { Control }\end{array}$ & 0.475 \\
\hline Time Management & 0.503 & $\begin{array}{l}\text { Know profit \& } \\
\text { loss }\end{array}$ & 0.549 & $\begin{array}{l}\text { Other Jobs Ops in } \\
\text { Market }\end{array}$ & 0.445 \\
\hline Training & 0.47 & Professionalism & 0.543 & Planning & 0.433 \\
\hline Perseverance & 0.457 & Respect & 0.525 & Person-Job Fit & 0.417 \\
\hline Budgeting & 0.446 & Innovation & 0.482 & Family Support & 0.413 \\
\hline Ability to Delegate & 0.433 & $\begin{array}{l}\text { Desire to Remain } \\
\text { in Job }\end{array}$ & 0.473 & Have Mentor & 0.389 \\
\hline Problem Solving & 0.426 & Open Minded & 0.456 & $\begin{array}{l}\text { Gets Along with } \\
\text { Others }\end{array}$ & 0.378 \\
\hline $\begin{array}{l}\text { Dealing with } \\
\text { Change }\end{array}$ & 0.424 & Self Discipline & 0.448 & $\begin{array}{l}\text { Previous Work } \\
\text { Experience }\end{array}$ & 0.34 \\
\hline Critical Thinking & 0.418 & Positive Attitude & 0.447 & Careful & 0.339 \\
\hline Know Flavors & 0.404 & $\begin{array}{l}\text { Positive } \\
\text { Atmosphere }\end{array}$ & 0.445 & Respect & 0.344 \\
\hline Work Pleasure & 0.337 & Passion & 0.385 & Innovation & 0.316 \\
\hline Previous Experience & 0.316 & $\begin{array}{l}\text { Keeps up with } \\
\text { Current Trends }\end{array}$ & 0.317 & $\begin{array}{l}\text { Desire to Remain } \\
\text { in Job }\end{array}$ & 0.366 \\
\hline $\begin{array}{l}\text { Know Menu } \\
\text { Development }\end{array}$ & 0.308 & & & Open Minded & 0.307 \\
\hline Professionalism & 0.454 & & & Self Discipline & 0.323 \\
\hline Self Discipline & 0.426 & & & & \\
\hline Positive Attitude & 0.346 & & & & \\
\hline Passion & 0.365 & & & & \\
\hline
\end{tabular}

current study though show that $44.1 \%$ were satisfied with their wages, with a further $27.6 \%$ being neutral and only $24.7 \%$ were dissatisfied with their wages. However, the current study does show that those who were working for a greater number of years in the industry were earning higher wages. In 


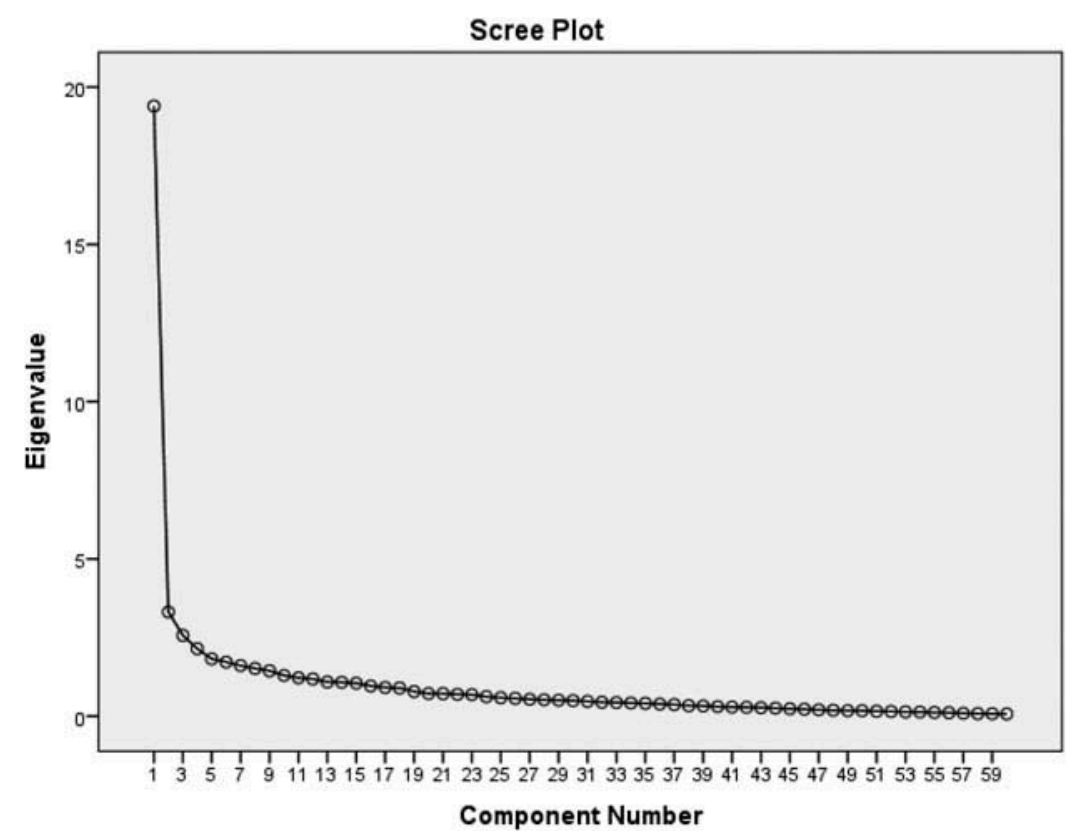

Figure 9. Scree plot for PO scale.

general, success as a chef and making it to the top of a kitchen brings rewards financially and many head chefs are satisfied with their earnings.

The fact that the star rating, the type of establishment (i.e., small family run business or a part of a large chain), and the size of the establishment where the chefs worked with seats/covers unaccounted for in the present study is a weakness that might have further explained variance in wages. Both Seibert and Kraimer (2001) and Melamed (1996) found that salaries were influenced by the size of the firm in which the individuals worked.

Subjective success was recorded in the ratings of job satisfaction, and the majority of head chefs $(80 \%)$ were satisfied in their jobs. Higher job satisfaction came with an increase in years working, although there was a slight dip in overall satisfaction until head chefs were working 10 years. However, older generations do have more job satisfaction than those newly qualified (Gursoy et al., 2008; Hertzman \& Maas, 2012). Job satisfaction also correlated with wages earned, thus confirming Arthur et al.'s (2005) assertion that objective and subjective career success are interdependent.

\section{Variables needed to succeed as a head chef and personal ownership of them}

The second aim of the current research was to investigate perceptions of what contributes to success of head chefs working in Ireland. Table 4 outlines the mean ratings of the 59 variables in descending order for both the NS scale and 


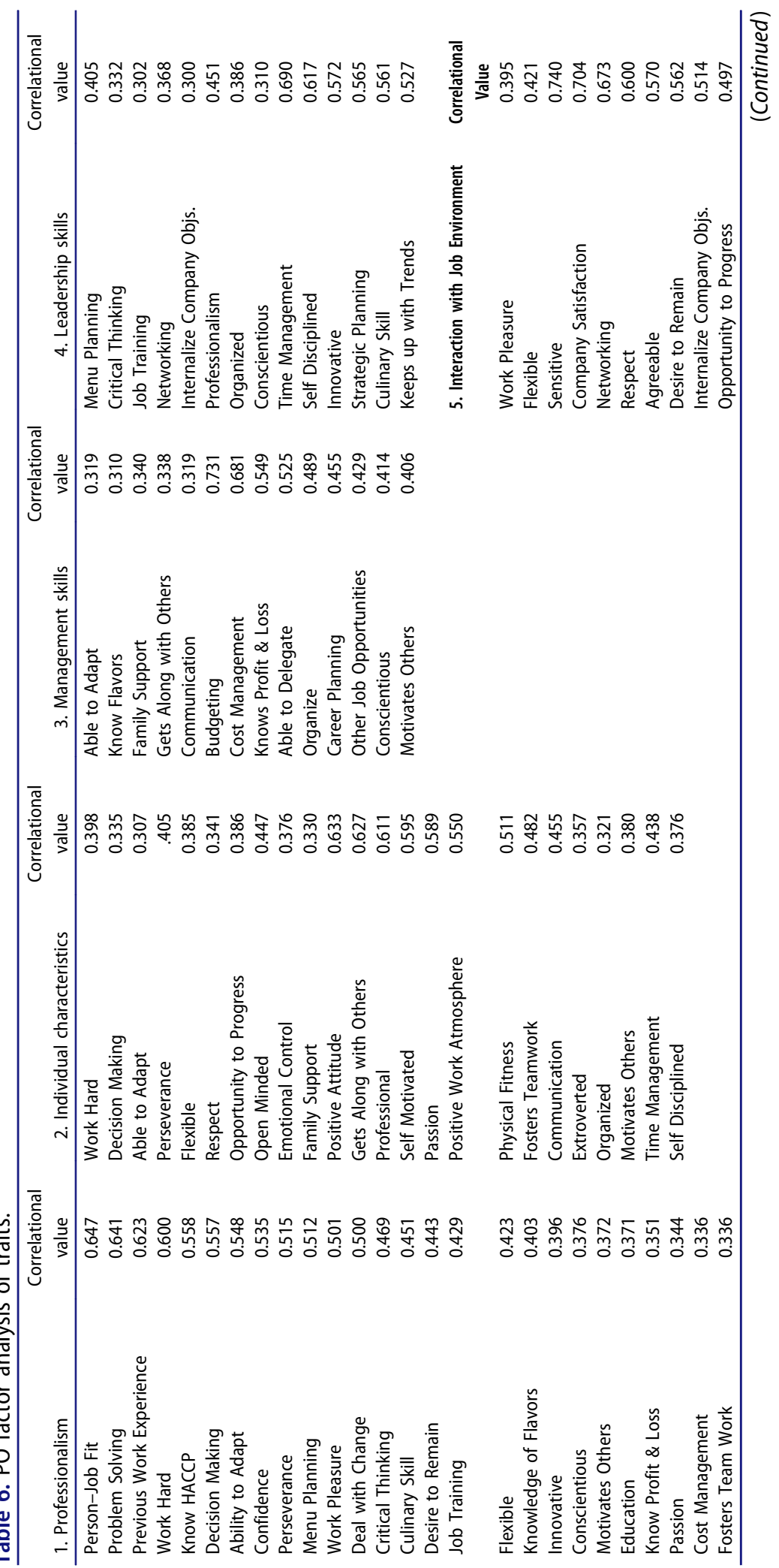




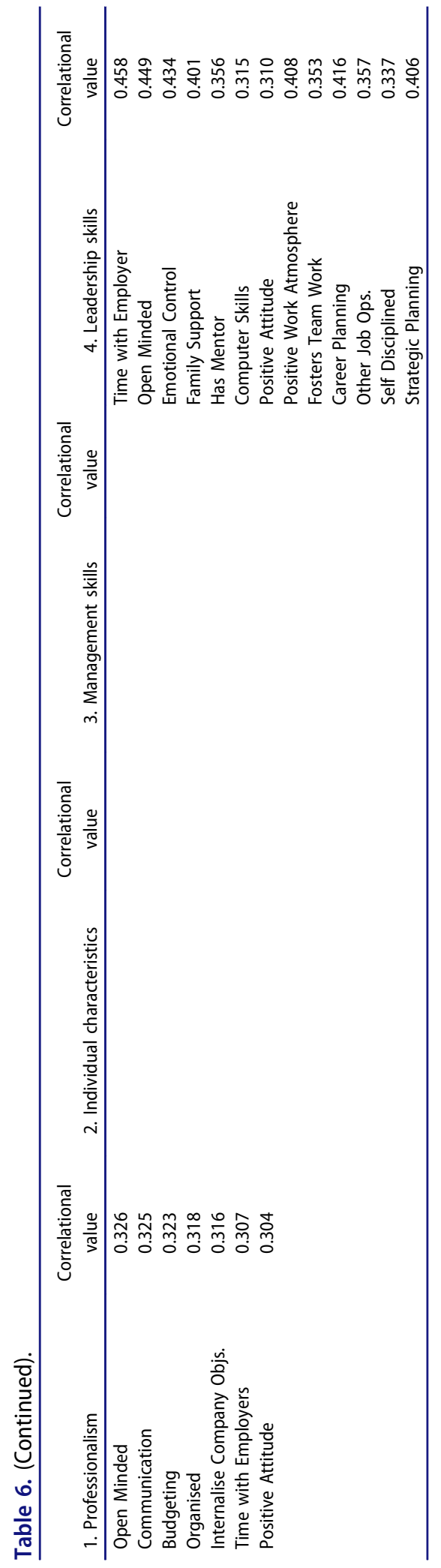


the PO scale. It is noteworthy that four of the top five traits on both scales are common: commitment to quality, ability to work hard, knowledge of HACCP, and knowledge of flavor. The top five traits are also found in the international literature on career success (Antun \& Salazar, 2005; Balazs, 2001, 2002; Dreher \& Bretz, 1991; Judge et al., 1995; Pratten, 2003; Zopiatis, 2010). Those variables that were rated lowest on the scales include networking, computer skills, and extraversion. However, even these variables were still rated as moderately important. How variables were rated had some commonalities and some differences to the results of the Cypriot chefs (Zopiatis, 2010) and Taiwanese food and beverage employees (Wang et al., 2011), but direct comparison with either these studies is not possible due to different methodologies, variables, and population samples. It was also found that demographics significantly impacted how the head chefs rated each of the scales.

\section{Importance-Performance analysis}

In answering the third research question of this study, importance-performance analysis highlights how results from both the NS and PO scales could be compared. Findings show four quadrants, which are labeled "concentrate here," "keep up the good work," "low priority," and "possible overkill." The most important quadrant of this analysis is the "concentrate here" section. Variables included: confidence, innovation, keeping up with current trends, self-discipline, communication, budgeting, cost management, motivating others, and delegating. This analysis provides useful data for culinary educators or industry bodies, such as the RAI, IHF, Bord Bia, and Fáilte Ireland, in developing continuous professional development courses. Innovation and keeping up with current trends is an emerging area of importance for chefs and the development of a master's course in this area in recent years has been a foresight for the culinary industry in Ireland. Concentrating on budgeting and cost management has also been an area that has been highlighted in research literature over the past number of years (Gilbert \& Guerrier, 1997; Raybould \& Wilkins, 2005; Zopiatis, 2010) and is of greater importance since the economic recession in Ireland.

\section{Factor analysis to develop culinary model for success}

The current study developed a measure of the variables for culinary success that were based on competencies, personality, and the context of the individual. In addressing RQ4, these measures were then subjected to factor analysis to group the variables together for easier summation of the factors influencing success that was specific to the culinary industry. Findings showed that the factors needed for success could be grouped as professionalism, leadership skills, and interaction with the job context. For how head chefs rated themselves, the factor analysis resulted in five groupings, which 
can be summarized as professionalism, individual characteristics, management skills, leadership skills, and interaction with the job environment. Interacting with the job context probably most reflects the work of Wang et al. (2011) and shows how individuals are impacted by education, personal outlooks, and having support in how they fit into and attain success with a company. While the job environment and context of employment were the lowest ranked factor in both the NS and PO scales, this factor did have a moderate correlation with success and should still be considered in Western cultures. This research shows the factors that are needed for success specifically within the culinary industry are broader in scope than Zopiatis' (2010) study, as competencies, character traits or personality, and the context of the workplace for head chefs all impact on their success.

\section{Recommendations and conclusion}

Culinary students should be aware that a broad range of skills and competencies is required from those who wish to progress to the top of the culinary world. Factors needed to succeed and those involved in becoming a successful head chef include professionalism, leadership skills, individual characteristics, management skills, and how the individual interacts within the job context or environment. Students should also be prepared to be patient for success, as the majority of head chefs who were earning the highest wages had been working for many years.

Results also highlight areas that head chefs may benefit from further training or continuous professional development courses. Perhaps these are areas that third-level institutes or supporting bodies could consider for running as short courses or evening classes.

Findings from the current study can also be used to build a model for success within the culinary workplace that develops tomorrow's industry leaders, both at the educational level but also at the industry level. Results can be used both in the development of curricula and also as key objectives in learning outcomes. In the industry, findings can be used at the recruitment, selection and training stages of employment, and also with talent management. Perhaps findings may even be useful for the development of performance appraisals, benchmarking, and reward systems in the continuous professional development of staff within the industry.

One factor that is growing in importance, both in Ireland and globally, but was not found in the literature was the area of social media, particularly rating sites such as TripAdvisor and Yelp, and the power of Twitter. Computer skills and communication were measured in this study, but it is important to note that head chef management of the online work environment or social media was not part of this study. Academic research in this area is sparse (Rousseau, 2012), but perhaps any future study might include 
it, or study the phenomenon of how a chef s life and satisfaction are impacted by social media separately.

Finally, the authors recommend that future scholars might test the findings from this article in other countries to see if there is a difference in how other cultures rate the factors for culinary success.

\section{ORCID}

Máirtín Mac Con Iomaire (i) http://orcid.org/0000-0001-6622-3299

\section{References}

Agut, S., Grau, R., \& Peiro, J. M. (2003). Competency needs among managers from Spanish hotel and restaurants and their training demands. International Journal of Hospitality Management, 22(3), 281-295. doi:10.1016/S0278-4319(03)00045-8

Akrivos, C., Ladkin, A., \& Reklitis, P. (2007). Hotel managers' career strategies for success. International Journal of Contemporary Hospitality Management, 19(2), 107-119. doi:10.1108/09596110710729229

Alexander, M., MacLaren, A., O'Gorman, K., \& Taheri, B. (2012). "He just didn't seem to understand the banter": Bullying or simply establishing social cohesion? Tourism Management, 33(5), 1245-1255. doi:10.1016/j.tourman.2011.11.001

Allen, H., \& Mac Con Iomaire, M. (2016). “Against all odds": Head chefs profiled. Journal of Culinary Science and Technology, 14(2), 107-135. doi:10.1080/15428052.2015.1080645

Amer, S. (2005). Bam. Successful Meetings, 54(6), 52-57.

Antun, J. M., \& Salazar, J. (2005). The impact of learning transfer outcomes on employed culinary arts graduates' perceptions of career success. Journal of Culinary Science \& Technology, 4(1), 75-87. doi:10.1300/J385v04n01_09

Arthur, M. B., Khapova, S. N., \& Wilderom, C. P. M. (2005). Career success in a boundaryless career world. Journal of Organizational Behavior, 26, 177-202. doi:10.1002/job.290

Aryee, S., \& Chay, Y. W. (1994). An examination of the impact of career-oriented mentoring on work commitment attitudes and career satisfaction among professional and managerial employees. British Journal of Management, 5, 241-249. doi:10.1111/bjom.1994.5.issue-4

Balazs, K. (2001). Some like it haute: Leadership lessons from France's great chefs. Organizational Dynamics, 30(2), 134-148. doi:10.1016/S0090-2616(01)00048-1

Balazs, K. (2002). Take one entrepreneur: The recipe for success of France's great chefs. European Management Journal, 20(3), 247-259. doi:10.1016/S0263-2373(02)00040-3

Bartholomew, P. S., \& Garey, J. G. (1996). An analysis of determinants of career success for elite female executive chefs. Journal of Hospitality and Tourism Research, 20(2), 125-135. doi:10.1177/109634809602000209

Berta, D. (2003, February). Vega's Sean Yontz puts on-the-job education to work. Nation's Restaurant News, 17, 28.

Birdir, K., \& Pearson, E. T. (2000). Research chefs' competencies: A Delphi approach. Journal of Contemporary Hospitality Management, 12(3), 205-209. doi:10.1108/09596110010309989

Bloisi, W., \& Hoel, H. (2008). Abusive work practices and bullying among chefs: A review of the literature. International Journal of Hospitality Management, 27(4), 649-656. doi:10.1016/j.ijhm.2007.09.001 
Bozionelos, N. (2008). Intra-organizational network resources: How they relate to career success and organizational commitment. Personnel Review, 37(3), 249-263. doi:10.1108/ 00483480810862251

Brien, A. (2004). The New Zealand hotel industry-Vacancies increase while applicant members and caliber decrease. International Journal of Hospitality \& Tourism Administration, 5(1), 87-104. doi:10.1300/J149v05n01_05

Bronfenbrenner, U. (1979). The ecology of human development. Cambridge, MA: Harvard University Press.

Bueno, C. M., \& Tubbs, S. L. (2004). Identifying global leadership competencies: An exploratory study. The Journal of American Academy of Business, Cambridge, 5(1/2), 80-87.

Butler, S., \& Skipper, J. K. (1983). Working the circuit: An explanation of employee turnover in the restaurant industry. Sociological Spectrum, 3, 19-33. doi:10.1080/ 02732173.1983 .9981679

Caraher, M. (2012, June). Cooking in crisis: Lessons from the UK. In Dublin Institute of Technology, Dublin Gastronomy Symposium, Dublin, Ireland. Retrieved from http:// arrow.dit.ie/dgs/2012/june512/6/.

Cheng, C. H. (2011). Integrating perspectives in career development theory and practice. The Career Development Quarterly, 51, 203-216. doi:10.1002/cdq.2003.51.issue-3

Chivers, T. S. (1972). Chefs and cooks: A study in the sociology of occupations. (Unpublished Manuscript, Doctoral Thesis) University of London.

Chung-Herrera, B. G., Enz, C. A., \& Lankau, M. J. (2003). Grooming future hospitality leaders: A competencies model. Cornell Hotel \& Restaurant Administration Quarterly, 44(3), 17-25.

Collins, A. B. (2001). Gateway to the real world, industrial training: Dilemmas and problems. Tourism Management, 23(1), 93-96. doi:10.1016/S0261-5177(01)00058-9

Davidson, M. C. G., McPhail, R., \& Barry, S. (2011). Hospitality HRM: Past, present and the future. International Journal of Contemporary Hospitality Management, 23(4), 498-516. doi:10.1108/09596111111130001

Davis, J. J. (2013). Defining culinary authority: The transformation of cooking in France, 1650-1830. Baton Rouge, LA: Louisiana State University Press.

De Vaus, D. A. (1993). Surveys in social research (3rd ed.). St. Leonard's, Australia: Allen \& Unwin.

De Vos, A., \& Soens, N. (2008). Protean attitude and career success: The mediating role of selfmanagement. Journal of Vocational Behavior, 73, 449-456. doi:10.1016/j.jvb.2008.08.007

Dreher, G. F., \& Bretz, R. D. (1991). Cognitive ability and career attainment: Moderating effects of early career success. Journal of Applied Psychology, 76(3), 392-397. doi:10.1037/ 0021-9010.76.3.392

Dries, N., Pepermans, R., \& Carlier, O. (2008). Career success: Constructing a multidimensional model. Journal of Vocational Behavior, 73, 254-267. doi:10.1016/j.jvb.2008.05.005

EGFSN. (2015). Assessment of future skills requirements in the hospitality sector in Ireland, 2015-2020 Retrieved from http://www.skillsireland.ie/Publications/2015/Assessment\%20of \%20Future\%20Skills\%20Requirements\%20in\%20the\%20Hospitality\%20Sector\%20in\% 20Ireland,\%202015-2020.html.

Feingold, D., Wagner, K., \& Mason, G. (2000). National skill-creation systems and career paths for service workers: Hotels in the United States, Germany and the United Kingdom. The International Journal of Human Resource Management, 11(3), 497-516. doi:10.1080/ 095851900339738

Fine, G. A. (1996). Justifying work: Occupational rhetorics as resources in restaurant kitchens. Administrative Science Quarterly, 41, 90-115. doi:10.2307/2393987 
Getz, D. (1994). Students' work experiences, perceptions and attitudes towards careers in hospitality and tourism: A longitudinal case study in Spey Valley, Scotland. International Journal of Hospitality Management, 13(1), 25-37. doi:10.1016/0278-4319(94)90057-4

Gilbert, D., \& Guerrier, Y. (1997). UK hospitality managers past and present. The Service Industries Journal, 17(1), 115-132. doi:10.1080/02642069700000006

Goyette, K. A. (2008). College for some to college for all: Social background, occupational expectations, and educational expectations over time. Social Science Research, 37, 461-484. doi:10.1016/j.ssresearch.2008.02.002

Gunz, H. P., \& Heslin, P. A. (2005). Reconceptualizing career success. Journal of Organizational Behavior, 26, 105-111. doi:10.1002/(ISSN)1099-1379

Gursoy, D., Maier, T. A., \& Chi, C. G. (2008). Generational differences: An examination of work values and generational gaps in the hospitality workforce. International Journal of Hospitality Management, 27, 448-458. doi:10.1016/j.ijhm.2007.11.002

Hansson, B. (2001). Competency models: Are self perceptions accurate enough? Journal of European Industrial Training, 25(9), 428-441. doi:10.1108/03090590110410205

Harrington, R. J. (2005). Chef as CEO: An analogy and teaching tool. Journal of Culinary Science and Technology, 4(1), 39-52. doi:10.1300/J385v04n01_06

Harris, D. A., \& Giuffre, P. (2015). Taking the heat: Women chefs and gender inequality in the professional kitchen. New Brunswick, NJ: Rutgers University Press.

Hegarty, J. A. (2004). Standing the heat: Ensuring curriculum quality in culinary arts and gastronomy. New York, NY: Haworth Hospitality Press.

Hertzman, J. L., \& Maas, J. (2012). The value of culinary education: Evaluating educational costs, job placement outcomes and satisfaction with value of associate degree in culinary and baking arts program graduates. Journal of Culinary Science \& Technology, 10(1), 53-74. doi:10.1080/15428052.2012.650609

Hofmans, J., Dries, N., \& Pepermans, R. (2008). The career satisfaction scale: Response bias among men and women. Journal of Vocational Behavior, 73, 397-403. doi:10.1016/j. jvb.2008.08.001

Horng, J. S., \& Lee, Y. C. (2006). What does it take to be a creative culinary artist? Journal of Culinary Science \& Technology, 5(2/3), 5-22.

Horng, J.-S., \& Lee, Y.-C. (2009). What environmental factors influence creative culinary studies? International Journal of Contemporary Hospitality Management, 21(1), 100-117. doi:10.1108/09596110910930214

Hu, M. L. M. (2010). Developing a core competency model of innovative culinary development. International Journal of Contemporary Hospitality Management, 29(4), 582-590. doi:10.1016/j.ijhm.2009.10.024

Hui, C. H. (1988). Impacts of objective and subjective labour market conditions on employee turnover. Journal of Occupational Psychology, 61, 211-219. doi:10.1111/joop.1988.61.issue-3

Iverson, R. D., \& Deery, M. (1997). Turnover culture in the hospitality industry. Human Resource Management Journal, 7(4), 71-82. doi:10.1111/hrmj.1997.7.issue-4

Jauhari, V. (2006). Competencies for a career in the hospitality industry: An Indian perspective. International Journal of Contemporary Hospitality Management, 18(2), 123-134. doi:10.1108/09596110610646673

Jepson, D. A., \& Dickson, G. L. (2003). Continuity in life-span career development: Career exploration as a precursor to career establishment. The Career Development Quarterly, 51, 217-233. doi:10.1002/j.2161-0045.2003.tb00603.x

Johns, N., \& Menzels, P. J. (1999). If you can't stand the heat!. . Kitchen violence and culinary art. International Journal of Hospitality Management, 18(2), 99-109. 
Johnston, N. E., \& Phelan, K. V. (2016). Assessing objective and subjective factors of culinary career success: Exploring the influence of industry certifications. Journal of Culinary Science \& Technology, 14(1), 36-58. doi:10.1080/15428052.2015.1080641

Joiner, T. A., Baartram, T., \& Garreffa, T. (2004). The effects of mentoring on perceived career success, commitment and turnover intentions. The Journal of American Academy of Business, Cambridge, 5(1/2), 164-170.

Judge, T. A., Cable, D. M., Boudreau, J. W., \& Bretz, R. D. (1995). An empirical investigation of the predictors of executive career success. Personnel Psychology, 48, 485-519. doi:10.1111/j.1744-6570.1995.tb01767.x

Judge, T. A., Higgins, C. A., Thoresen, C. J., \& Barrick, M. R. (1999). The big five personality traits, general mental ability and career success across the life span. Personnel Psychology, 52, 621-652. doi:10.1111/peps.1999.52.issue-3

Katz, R. L. (1955). Skills of an effective administrator. Harvard Business Review, Jan-Feb, $33-42$.

Ko, W.-H. (2012). A study of the relationships among effective learning, professional competence, and learning performance in culinary field. Journal of Hospitality, Leisure, Sport \& Tourism Education, 11(1), 12-20. doi:10.1016/j.jhlste.2012.02.010

Kuijpers, M., Schyns, B., \& Scheerens, J. (2006). Career competencies for career success. The Career Development Quarterly, 55, 166-178. doi:10.1002/j.2161-0045.2006.tb00011.x

Ladkin, A. (2000). Vocational education and food and beverage experience: Issues for career development. International Journal of Contemporary Hospitality Management, 12 (4), 226-233. doi:10.1108/09596110010330723

Lee-Ross, D. (2001). An exploratory study of work motivation among private and public sector hospital chefs in Australia. Journal of Management Development, 21(7/8), 576-589. doi:10.1108/02621710210437554

LeVine, E. (2007). Recruiting, training and retaining: Your most valuable tools are your employees. Chef Magazine, 51(6), 19.

Lub, X., Bijvank, M. N., Bal, P. M., Blomme, R., \& Schalk, R. (2012). Different of alike? Exploring the psychological contract and commitment of different generations of hospitality workers. International Journal of Contemporary Hospitality Management, 24(4), 553-573. doi:10.1108/09596111211226824

Lydon, J. (2012). Who should train our chefs in Ireland? In Dublin Institute of Technology, Dublin Gastronomy Symposium. Dublin June 5, 2012. Retrieved from http://arrow.dit.ie/ dgs/2012/june512/22/ (Accessed 25 May, 2013).

Mac Con Iomaire, M. (2008). Understanding the heat-Mentoring: A model for nurturing culinary talent. Journal of Culinary Science \& Technology, 6(1), 43-62. doi:10.1080/ 15428050701884196

Mac Con Iomaire, M. (2013). Public dining in Dublin: The history and evolution of gastronomy and commercial dining 1700-1900. International Journal of Contemporary Hospitality Management, 25(2), 227-246. doi:10.1108/09596111311301612

Mac Con Iomaire, M. (2014). "From Jammet's to Guilbaud's": The influence of French haute cuisine on the development of Dublin Restaurants. In M. Mac Con Iomaire \& E. Maher (eds.), "Tickling the palate": Gastronomy in Irish literature and culture (pp. 121-141). Oxford, UK: Peter Lang.

Mac Con Iomaire, M. (2015). Haute cuisine restaurants in nineteenth- and twentieth-century Ireland. Proceedings of the Royal Irish Academy, 115C, 371-403. doi:10.3318/ PRIAC.2015.115.06

Magnusson Sporre, C., Johnson, I. M., \& Ekström, M. P. (2015). The complexity of making a conscious meal: A concept for development and education. Journal of Culinary Science \& Technology, 13(3), 263-285. doi:10.1080/15428052.2015.1015668 
Martilla, J. A., \& James, J. C. (1977). Importance-Performance analysis. Journal of Marketing, 41, 77-79. doi:10.2307/1250495

Martin, E. (2004). Who's kicking whom? Employees' orientations to work. International Journal of Contemporary Hospitality Management, 16(3), 182-188. doi:10.1108/ 09596110410531177

Melamed, T. (1996). Validation of a stage model of career success. Applied Psychology: An International Review, 45(1), 35-65. doi:10.1111/apps.1996.45.issue-1

Mennell, S. (1996). All manners of rood (2nd ed.). Chicago, IL: University of Illinois Press.

Mesch, B. D. (2012). The influence of extracurricular food service work experience on culinary graduate industry experience. Journal of Culinary Science and Technology, 10(1), 19-39. doi:10.1080/15428052.2012.650603

MRCI. (2008). Exploitation in Ireland's restaurant industry. Retrieved from http://www.mrci. ie/resources/publications/leaflets-reports/exploitation-in-irelands-restaurant-industry/.

Murray-Gibbons, R., \& Gibbons, C. (2007). Occupational stress in the chef profession. International Journal of Contemporary Hospitality Management, 19(1), 32-42. doi:10.1108/09596110710724143

Ng, C. W., \& Pine, R. (2003). Women and men in hotel management in Hong Kong: Perceptions of gender and career development issues. International Journal of Hospitality Management, 22, 85-102. doi:10.1016/S0278-4319(02)00077-4

Nicholson, N., \& De Waal-Andrews, W. (2005). Playing to win: Biological imperatives, selfregulation, and trade-offs in the game of career success. Journal of Organizational Behavior, 26, 137-154. doi:10.1002/(ISSN)1099-1379

Nordhaug, O. (1998). Competence specificities in organizations. International Studies of Management \& Organization, 28(1), 8-29. doi:10.1080/00208825.1998.11656725

Oppenheim, A. N. (1992). Questionnaire design, interviewing and attitude measurement. London, England: Cassell.

Osgood, C. E. (1964). Semantic differential technique in the comparative study of cultures. American Anthropologist, 66(3), 171-200. doi:10.1525/aa.1964.66.3.02a00880

Parkhurst-Ferguson, P., \& Zukin, S. (1998). The career of chefs. In R. Scapp \& B. Seitz (eds.), Eating culture (pp. 92-111). New York, NY: State University of New York Press.

Parseghian, P. (1995). Helmut Schweden: Showering students with skill. Nation's Restaurant News, 29(14), 59.

Pratten, J. D. (2003). The training and retention of chefs. International Journal of Contemporary Hospitality Management, 15(4), 237-242. doi:10.1108/09596110310475702

RAI. (2013). Restaurants association of Ireland launches its pre-budget 2014 submission. Retrieved from http://www.rai.ie/news-restaurants-association-of-ireland-launches-itspre-budget-2014-submission-195.html.

Raybould, M., \& Wilkins, H. (2005). Overqualified and under-experienced: Turning graduates into hospitality managers. International Journal of Contemporary Hospitality Management, 17(3), 203-216. doi:10.1108/09596110510591891

Robinson, R. N. S., \& Barron, P. E. (2007). Developing a framework for understanding the impact of deskilling and standardisation on the turnover and attrition of chefs. International Journal of Hospitality Management, 26(4), 913-916. doi:10.1016/j. ijhm.2006.10.002

Robinson, R. N. S., \& Beesley, L. G. (2010). Linkages between creativity and intention to quit: An occupational study of chefs. Tourism Management, 31(6), 765-776. doi:10.1016/j. tourman.2009.08.003

Rousseau, S. (2012). Food and Social Media: You Are What You Tweet. Plymouth, UK: Altamira Press. 
Sandwith, P. (1993). A hierarchy of management training requirements: The competency domain model. Public Personnel Management, 22(1), 43-62. doi:10.1177/009102609302200104

Seibert, S. E., \& Kraimer, M. L. (2001). The five-factor model of personality and career success. Journal of Vocational Behavior, 58, 1-21. doi:10.1006/jvbe.2000.1757

Sengupta, A., Venkatesh, D. N., \& Sinha, A. K. (2013). Developing performance-linked competency model: A tool for competitive advantage. International Journal of Organizational Analysis, 21(4), 504-527. doi:10.1108/IJOA-05-2011-0488

Sheehan, K. (2014). Hospitality 2015. Retrieved from http://www2.deloitte.com/ie/en/pages/ consumer-business/articles/hospitality-2015.html.

Spang, R. L. (2000). The invention of the restaurant: Paris and modern gastronomic culture. Cambridge, MA: Harvard University Press.

Steinberg, J. (2010). The case for not going to college: Many in-demand jobs in the U.S. don't require an advanced education. The International Herald Tribune, 17(May), 2.

Stierand, M., \& Lynch, P. (2008). The art of creating culinary innovations. Tourism \& Hospitality Research, 8(4), 337-350. doi:10.1057/thr.2008.28

Taylor, E., \& Taylor, J. (1990). Mastering catering theory. London, UK: Macmillan Education.

Tu, H. S., Forret, M. L., \& Sullivan, S. E. (2006). Careers in a non-Western context: An exploratory empirical investigation of factors related to the career success of Chinese managers. Career Development International, 11(7), 580-593. doi:10.1108/13620430610713454

Valcour, M., \& Ladge, J. J. (2008). Family and career path characteristics as predictors of women's objective and subjective career success: Integrating traditional and protean career explanations. Journal of Vocational Behavior, 73, 300-309. doi:10.1016/j.jvb.2008.06.002

Wang, Y. F., Horng, J. S., Cheng, S. Y., \& Killman, L. (2011). Factors influencing food and beverage employees' career success: A contextual perspective. International Journal of Hospitality Management, 30(4), 997-1007. doi:10.1016/j.ijhm.2011.03.005

Whyte, W. F. (1948). Human relations in the restaurant industry. New York, NY: McGrawHill.

Wong, S. C., \& Ladkin, A. (2008). Exploring the relationship between employee creativity and job-related motivators in the Hong Kong hotel industry. International Journal of Hospitality Management, 27, 426-437. doi:10.1016/j.ijhm.2008.01.001

Wood, R. C. (1997). Working in Hotels and Catering (2nd ed.). London, UK: International Thompson Business Press.

Wu, P.-C., Foo, M.-D., \& Turban, D. B. (2008). The role of personality in relationship closeness, developer assistance, and career success. Journal of Vocational Behavior, 73, 440-448. doi:10.1016/j.jvb.2008.08.005

Zetie, S., Sparrow, J., Woodfield, A., \& Kilmartin, T. (1994). The tyrannical chef: A barrier to TQM? International Journal of Contemporary Hospitality Management, 6(1/2), 42-45. doi:10.1108/09596119410052116

Zopiatis, A. (2010). Is it art or science? Chef's competencies for success. International Journal of Hospitality Management, 29, 459-467. doi:10.1016/j.ijhm.2009.12.003

Zopiatis, A., \& Constanti, P. (2007). And never the twain shall meet: Investigating the hospitality industry-Education relationship in Cyprus. Education and Training, 49(5), 391-407. doi:10.1108/00400910710762959 